\title{
Striatins as plaque molecules of zonulae adhaerentes in simple epithelia, of tessellate junctions in stratified epithelia, of cardiac composite junctions and of various size classes of lateral adherens junctions in cultures of epithelia- and carcinoma-derived cells
}

\author{
Werner W. Franke • Steffen Rickelt • Ralf Zimbelmann • \\ Yvette Dörflinger • Caecilia Kuhn • \\ Norbert Frey • Hans Heid • Rina Rosin-Arbesfeld
}

Received: 10 July 2014 / Accepted: 5 November 2014 /Published online: 12 December 2014

(C) The Author(s) 2014. This article is published with open access at Springerlink.com

\begin{abstract}
Proteins of the striatin family (striatins 1-4; sizes ranging from 90 to $110 \mathrm{kDa}$ on SDS-polyacrylamide gel electrophoresis) are highly homologous in their amino acid sequences but can differ in their cell-type-specific gene expression patterns and biological functions. In various cell
\end{abstract}

With regards to general nomenclature, we prefer the use of striatins 1-4 instead of the names striatin, $\mathrm{SG} 2 \mathrm{Na} \alpha, \mathrm{SG} 2 \mathrm{Na} \beta$, and zinedin (for details, see review of Hwang and Pallas 2013).

This work was supported by a grant from the German-Israeli Foundation for Scientific Research and Development (GIF grant I-1098-43.11/2010).

Electronic supplementary material The online version of this article (doi:10.1007/s00441-014-2053-z) contains supplementary material, which is available to authorized users.

W. W. Franke $(\bowtie) \cdot S$. Rickelt · R. Zimbelmann · Y. Dörflinger • C. Kuhn $\cdot$ H. Heid

Helmholtz Group for Cell Biology, German Cancer Research Center (DKFZ), Im Neuenheimer Feld 280, 69120 Heidelberg, Germany

e-mail: w.franke@dkfz.de

W. W. Franke $\cdot$ C. Kuhn

Progen Biotechnik, Heidelberg, Germany

S. Rickelt

David H. Koch Institute for Integrative Cancer Research,

Massachusetts Institute of Technology (MIT), Cambridge, Mass., USA

\section{N. Frey}

Department of Internal Medicine III (Cardiology and Angiology), University Medical Center Schleswig-Holstein, Campus Kiel, Kiel, Germany

R. Rosin-Arbesfeld

Department of Clinical Microbiology and Immunology, Sackler

School of Medicine, Tel-Aviv University, Tel-Aviv, Israel types, we have found one, two or three polypeptides of this evolutionarily old and nearly ubiquitous family of proteins known to serve as scaffold proteins for diverse protein complexes. Light and electron microscopic immunolocalization methods have revealed striatins in mammalian cellcell adherens junctions (AJs). In simple epithelia, we have localized striatins as constitutive components of the plaques of the subapical zonulae adhaerentes of cells, including intestinal, glandular, ductal and urothelial cells and hepatocytes. Striatins colocalize with E-cadherin or E-N-cadherin heterodimers and with the plaque proteins $\alpha$ - and $\beta$-catenin, p120 and p0071. In some epithelia and carcinomas and in cultured cells derived therefrom, striatins are also seen in lateral AJs. In stratified epithelia and in corresponding squamous cell carcinomas, striatins can be found in plaques of some forms of tessellate junctions. Moreover, striatins are major plaque proteins of composite junctions (CJs; areae compositae) in the intercalated disks connecting cardiomyocytes, colocalizing with other CJ molecules, including plectin and ankyrin-G. We discuss the "multimodulator" scaffold roles of striatins in the initiation and regulation of the formation of various complex particles and structures. We propose that striatins are included in the diagnostic candidate list of proteins that, in the CJs of human hearts, can occur in mutated forms in the pathogeneses of hereditary cardiomyopathies, as seen in some types of genetically determined heart damage in boxer dogs.

Keywords Adherens junctions - Tessellate junctions .

Composite junctions $\cdot$ Intercalated disks $\cdot$ Arrhythmogenic ventricular cardiomyopathy (AC) $\cdot$ Dilated cardiomyopathy (DC) 


\section{Introduction}

The adhering junctions, i.e. desmosomes (maculae adhaerentes) and adherens junctions (AJs), are major and important elements of the cell-cell connection system in tissues (Farquhar and Palade 1963; for a recent review, see Franke 2009). In the last two decades, the list of the various subtypes of these junctions has been extended by several celltype-specific forms, including the complexus adhaerens of endothelial cells in certain types of lymph vessels (e.g. Schmelz and Franke 1990, 1993; Schmelz et al. 1994; for a review, see Moll et al. 2009) and the taproot junctions (manubria adhaerentia) of various mesenchymal cells (Wuchter et al. 2007). Of special physiological and medical interest are the myocardiac composite junctions (CJs; areae compositae) that form during the late fetal and postnatal heart development of diverse mammals and that represent densepacked amalgamated arrays of molecules known as desmosomal, peridesmosomal and $\mathrm{AJ}$ components of simple epithelia (e.g. Borrmann et al. 2000, 2006; Franke et al. 2006, 2013, 2014; Pieperhoff and Franke 2007; Pieperhoff et al. 2008). The importance of this type of junction became evident from developmental studies of gene knock-out mice lacking plakoglobin or plakophilin-2 (Bierkamp et al. 1996; Ruiz et al. 1996; Grossmann et al. 2004) and from discoveries of specific, genetically determined cardiomyopathies in human and animal hearts (e.g. Gerull et al. 2004; Antoniades et al. 2006; Heuser et al. 2006; van Tintelen et al. 2006, 2007; Oxford et al. 2007a, b; Posch et al. 2008; Gehmlich et al. 2011; Gaertner et al. 2012; for the recent avalanche of literature, see reviews by Delmar and McKenna 2010; Murray 2012; Rickelt and Pieperhoff 2012; Patel and Green 2014).

In this context, a series of findings concerning hereditary cardiomyopathies in boxer dogs is remarkable; these have been reported to be based on a genetic predisposition for special forms of dilated cardiomyopathy (DC) or arrhythmogenic cardiomyopathy (AC). So far, this seems to be the only pathogenic situation known to involve mutations in a gene encoding a myocardiac member of the striatin family ("striatin mutations"; e.g. Meurs et al. 1999, 2007, 2010, 2013; Oxford et al. 2007a, 2011). Striatin 1 has repeatedly been reported to be specific for neural cells and functions (e.g. Castets et al. 1996, 2000; Bartoli et al. 1998, 1999; Kachidian et al. 1998; Salin et al. 1998; for other striatins, see also Muro et al. 1995; Moreno et al. 2000; for reviews, see Benoist et al. 2006; Hwang and Pallas 2013). On the other hand, Meurs et al. (2013) have claimed that myocardiac striatin is a desmosomal protein, whereas Breitman et al. (2008) have reported that striatins do not occur in desmosomes but in other kinds of junctions of epithelia and carcinoma cells (for a review, see Hwang and Pallas 2013). The elucidation and examination of possible pathogenic roles of mutated striatins is obviously necessary as these proteins are known as architectonic scaffold molecules able to form oligomers and complexes with other proteins, including kinases and phosphatases, calmodulin and specific $\mathrm{Ca}^{2+}$-binding proteins, cortactin-binding proteins and signal formation, transduction or vesicle translocation proteins (e.g. Muro et al. 1995; Kachidian et al. 1998; Salin et al. 1998; Bartoli et al. 1999; Moreno et al. 2000; Gaillard et al. 2001, 2006; Yu et al. 2001; Blondeau et al. 2003; Lu et al. 2004; Benoist et al. 2006; Goudreault et al. 2009; Gordon et al. 2011; Bobik 2012; Chen et al. 2012; Tanti et al. 2014; for a review, see Hwang and Pallas 2013).

As the members of the striatin family are highly homologous in their amino acid sequences, and as these isoforms and their splice variants can occur in cell-type-specific patterns, we have decided to address the family of striatin molecules in general in this report and will deal with the diverse cell-typespecific polypeptide isoforms, splice variants and biosynthesis details of striatins in a subsequent protein-chemical-oriented publication.

\section{Materials and methods}

Tissues and cell cultures

Bovine tissue samples were obtained from the regional slaughterhouse (Mannheim, Germany) and murine (rat and mouse) tissues were from animals of the laboratory-animal facilities of the German Cancer Research Center (Heidelberg, Germany; for details, see Franke et al. 2006). In addition, tissue specimens from fetal German landrace pigs and 3year-old boars were obtained from the Institute of Farm Animal Genetics (Friedrich-Loeffler-Institute, Mariensee, Germany; see Rickelt et al. 2011). Cryopreserved human tissue samples, including tumour tissues, were obtained from material taken and examined for diagnostic pathology (Franke et al. 2006; Moll et al. 2009) or were provided by the National Center for Tumor Diseases (NCT, Heidelberg, Germany). In general, the samples were fixed either with $4 \%$ formaldehyde in phosphate-buffered saline (PBS) and embedded in paraffin or were snap-frozen in isopentane that had been precooled in liquid nitrogen and were then stored at $-80{ }^{\circ} \mathrm{C}$ until use. Protein lysates of frozen tissues were used for SDSpolyacrylamide gel electrophoresis (SDS-PAGE) of peptides (see Franke et al. 2013).

Monolayer cell cultures of various human cell lines were examined, including the breast-adenocarcinoma-derived line MCF-7, HaCaT keratinocytes, the colon-adenocarcinomaderived lines $\mathrm{CaCo} 2$ and HT29 and the hepatocellularcarcinoma-derived cell lines PLC, HepG2, Hep3b and $\mathrm{HuH7}$. Bovine epithelium-derived cell lines included mammary-gland-derived cells of lines BMGE, BMGE $+\mathrm{H}$, $\mathrm{BMGE}+\mathrm{HE}$ and KE-5. For comparison, rat liver hepatocellular carcinoma cells of the line $\mathrm{MH} 1 \mathrm{C} 1$ were studied in parallel. 
The non-epithelial cell lines tested included the human cell lines U333/MG, K562, RPMI 8226, HL-60, SV80, WI-38 and $\mathrm{RD}$, the bovine cell line $\mathrm{B} 1$, the rat cell line RVFSMC and the mouse cell lines 3 T3 and L929 (for further information, see Boda-Heggemann et al. 2009; Straub et al. 2011; Pieperhoff et al. 2012; Franke et al. 2013). In addition, freshly prepared cultures of human endothelial cells (HUVECs) and rat cardiomyocytes were used as described (cf. Pieperhoff et al. 2012).

\section{Antibodies}

Primary monoclonal antibodies (mAbs) and guinea pig polyclonal antibodies (pAbs) were generated against several amino acid sequences (Table 1) of striatin family members obtained as polypeptides synthesized by PSL (Peptide Speciality Laboratories, Heidelberg, Germany). The peptides, coupled via cysteines to keyhole limpet haemocyanin (KLH), were used for the immunization of animals, in particular mice and guinea pigs. Further antibodies against proteins of the striatin family or other molecules used in biochemical and immunolocalization experiments are listed in the Electronic supplementary material (Table S1) and in the publication by Straub et al. (2003).

The protocols in which murine mAbs, guinea pig pAbs and other antibodies were used for immunofluorescence microscopy or for immunoblotting analyses of PAGE-separated polypeptides against AJ molecules or against diverse cytoskeletal proteins were as described elsewhere (Rickelt et al. 2011). The newly generated mAbs and pAbs were routinely compared with "anti-striatin" and "anti-SG2NA" mAbs purchased from Becton-Dickinson (Heidelberg, Germany) or Millipore (Temecula, Calif., USA) and with commercially available polyclonal rabbit antibodies against striatin 4 ("zinedin"; Acris Antibodies, Herford, Germany). Antigen-

Table 1 Synthetic peptides (amino acid sequences) of striatin 1 used for coupling to keyhole limpet haemocyanin $(K L H)$ protein and antibody production in guinea pigs ( $N T$ aminoterminal sequence, $C T$ carboxyterminal sequence, $h$ human). The same KLH-coupled peptides were used in a second immunization series. The dot in the aminoterminal sequence (N P) stands for a histidine residue left out at this position in the antigenic peptide. "Striatin mix" (see text) is a mixture of equal portions of all four antisera

\begin{tabular}{|c|c|c|}
\hline Name & Amino acid sequence & $\begin{array}{l}\text { Amino acid (aa) } \\
\text { numbers }\end{array}$ \\
\hline Striatin-hNT & $\begin{array}{l}\text { MDEQAGPGVFFSNN P-C- } \\
\text { KLH }\end{array}$ & aa $1-16$ \\
\hline Striatin-h268 & RKKALPDSGEDRD-C-KLH & aa $268-280$ \\
\hline Striatin-h301 & $\begin{array}{l}\text { SRSAGDGTDWEKEDQ-C- } \\
\text { KLH }\end{array}$ & aa $301-316$ \\
\hline $\begin{array}{l}\text { Striatin family- } \\
\text { hCT }\end{array}$ & $\begin{array}{l}\text { KLH-C-YIASAG } \\
\text { ADALAKVFV }\end{array}$ & aa $765-780$ \\
\hline
\end{tabular}

bound primary Abs were visualized with secondary antibodies coupled to Cy3 (Dianova, Hamburg, Germany) or Alexa 488 (MoBiTec, Göttingen, Germany). For immunoblot analysis, horseradish-peroxidase-conjugated secondary antibodies were applied (Dianova).

Gel electrophoresis and immunoblotting

Protein lysates were analysed by SDS-PAGE, followed by immunoblotting, as described (Rickelt et al. 2011; Pieperhoff et al. 2012; Franke et al. 2013).

Immunofluorescence and immunoelectron microscopy

Methods for immunofluorescence and electron microscopy were as previously described (Franke et al. 2006, 2013; Rickelt et al. 2011; Pieperhoff et al. 2012; Rickelt 2012).

\section{Results}

Characterization of striatin proteins and antibodies

At least three genes encoding striatins of highly homologous amino acid sequences (striatins 1, 3, 4) have been identified, each with a series of introns. These genes and introns can result in different cell-type expression patterns of the various isoforms and splice variants. In the present report, we have therefore tried to generate certain polypeptide-sequencespecific antibodies, including some that are specific for certain unique sequence epitopes and others that cross-react between different striatins (see Materials and methods, Table 1).

Using the above antibodies and several that were commercially available, we identified striatins in all normal and tumour cells examined, including single blood cells and tissue cells and in cultured cells and tumour cells (Fig. 1a, b). Whereas some of these antibodies revealed the presence of at least two polypeptide bands of approximately 110 and $100 \mathrm{kDa}$ (Fig. 1a), other sequence-specific antibodies reacted with only one polypeptide (cf. Fig. 1b, b'). The common bands identified by some of the antibodies often appeared rather faint on some tissues, notably those of liver and heart, but were much more intense at higher protein loads or after extended immunoblot exposure times (see also Electronic supplementary material, Fig. S1). When various preparations of mammalian heart tissue or murine cardiomyocyte cell cultures were compared, a band with an $\mathrm{M}_{\mathrm{r}}$ of approximately $110 \mathrm{kDa}$ was always seen and, in some preparations, was accompanied by a (mostly minor) band of a lower $\mathrm{M}_{\mathrm{r}}$ (the obvious difference with respect to the SDS-PAGE immunoblot data of Castets et al. 2000, who reported only cardiac 

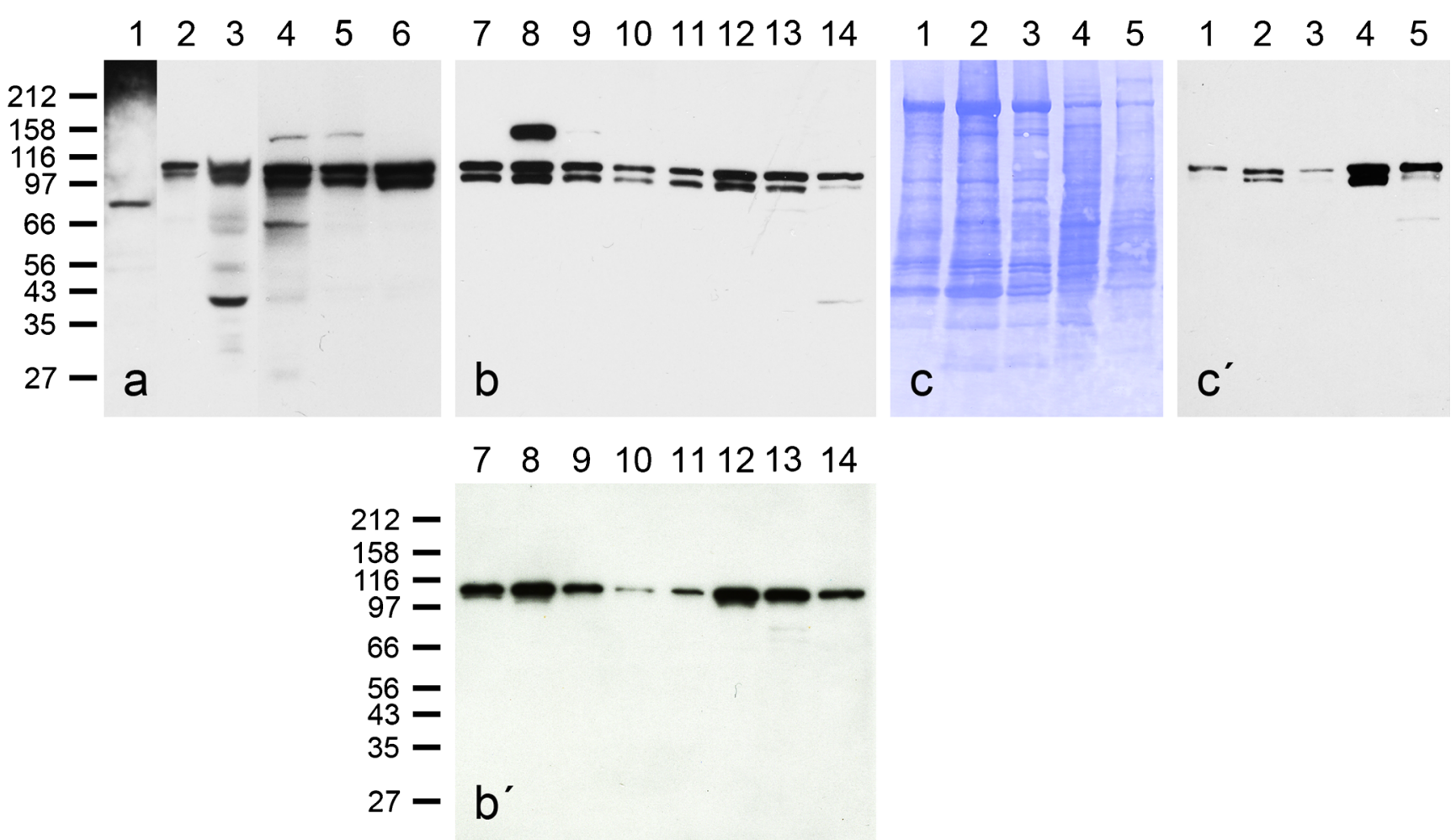

Fig. 1 Results of SDS-polyacrylamide gel electrophoresis (SDS-PAGE)separated polypeptides as obtained by immunoblot reactions $\left(\mathbf{a}, \mathbf{b}, \mathbf{b}^{\prime}, \mathbf{c}^{\prime}\right)$ or Coomassie blue staining (c). The antibodies used were monoclonal antibody (mAb) "Striatin" (Becton-Dickinson; a, b, c') and polyclonal antibody (pAb) raised in guinea pig (gp), namely "striatin mix" of NTB, 268B, 301B and CTB (b'). The tissue and cell lysis protein preparations used were from human heart (lane 1), tongue mucosa (lane 2), liver tissue (lane 3) and the following human cell culture lines: PLC (lane 4), HaCaT (lane 5), SV80 (lane 6), A498 (lane 7), CaCo2 (lane 8), A431 (lane 9), HeLa (lane 10), HUVEC cells (secondary cell culture; lane 11), K562 culture 01 (lane 12), K562 culture 02 (lane 13) and RPMI 8226 culture 01 (lane 14). In the results shown in $\mathbf{c}$ and $\mathbf{c}$, the following materials were

polypeptides of lower $\mathrm{M}_{\mathrm{r}}$ values, i.e. approximately 94 and $100 \mathrm{kDa}$, cannot yet be explained).

\section{Colocalization experiments}

Because of the dense-packing of cytoskeletal and cell junction components, special and carefully controlled antibody binding and differential washing protocols are needed to distinguish true and specific epitope binding from the various forms of structure and protein "stickiness". In the present study, we have generally included diverse washing steps to remove nonspecifically bound ("sticky") material from the structures in question, and in a series of cases, this required brief $(5,10$ or $15 \mathrm{~min}$ ) rinsing with mild detergent-containing buffers and/or acetone solutions. To illustrate the importance of such differential washing steps, we include here, as an example, the binding and release reactions of desmoplakin and plectin (Electronic Supplementary Material, Fig. S2). Whereas desmoplakin is known as an extraction-resistant, intensely used: human heart tissue (lane 1), bovine heart tissue (lane 2), murine heart tissue (mouse; lane 3), murine HL-1 culture line of cardiomyocytes (lane 4), and a primary cell culture of neonatal rat cardiomyocytes (lane 5). Note the dominant immunoblot polypeptide band at approximately $110 \mathrm{kDa}$ in all tissues and cell cultures, except for the weak reaction in lane 1 of a, which is, however, more noticeable at higher protein loadings. In addition, an immunoreactive band at approximately $100 \mathrm{kDa}$ is seen in most lanes of $\mathbf{a}, \mathbf{b}$ and in lanes 2, 4 of $\mathbf{c}^{\prime}$. In specific lanes of $\mathbf{a}$ and in lane 8 of $\mathbf{b}$, additional bands are notable that have not yet been characterized. Further reaction bands are seen at approximately $100 \mathrm{kDa}(\mathbf{a}, \mathbf{b}$, lanes 2, 4 in c) and at approximately $142 \mathrm{kDa}$ (lanes 4,5 in $\mathbf{a}$, lane 8 in $\mathbf{b}$ )

binding component of the CJs in the intercalated disks of the myocardium, plectin is, in addition, known for its marked "sticky" behaviour, i.e. binding that is not immunologically determined. Consequently, the plectin reaction with the sarcomeric Z-lines can (and should) be removed by differential washing (Fig. S2; cf. Fig. S2a, b). On the other hand, in the course of these washing steps, a significant portion of the plectin antibodies remain bound to the CJs, thus resulting, together with established CJ markers, such as desmoplakin, in a typical yellow merged reaction colour (Fig. S2a", b"). For example, the differential localization reaction of a "sticky" protein and a CJ-specific plaque protein is shown in Fig. S3, comparing striatin as a CJ-specific protein with $\alpha$-actinin as a "sticky" sarcomeric Z-line protein (Fig. S3; cf. Bennett et al. 2006). By contrast, various types of antibodies against $\alpha$ actinin colocalize with high precision and intensity (see the yellow merged patttern in Fig. S4). Consequently, extensive differential washing treatments have been included in the immunolocalization experiments of this study. 
Light microscopic immunolocalization in simple epithelial tissues

Using various antibodies against members of the striatin family on cryostat sections of diverse forms of simple epithelia, we have obtained a distinct immunolocalization pattern marking the upper portion in the zonula adhaerens. Figure 2a-a", for example, presents bovine intestinal epithelium. At the limited resolution in such semithin sections, the striatin reaction, for the most part, overlaps with that of the apical-most desmosomes (yellow merger colour), whereas the desmosomes lying more basally on the lateral cell membranes do not react at all or overlap optically with striatin antibodies (e.g. Fig. 2b). In thin sections, however, one can even locally often distinguish a specific thin apical striatin-positive zonula-like structure from the subjacent general zonula adhaerens region reacting, for example, with $\alpha$-catenin, $\beta$-catenin, p120, p0071 and protein ZO-1 (for $\beta$-catenin, see Fig. $2 \mathrm{c}-\mathrm{e}$ ). In such thin sections, the striatin and $\beta$-cadherin-positive zones can also be distinguished from the adjacent occludin- and claudin-positive zonulae occludentes of tight junctions (TJ; not shown). This subapical zonula region is also different from the zonula reaction sites of the $21-\mathrm{kDa}$ transmembrane protein PERP (Fig. 2"'; the apical zone under discussion here is demarcated by the bracket symbol in Fig. 2b). Similar results have been obtained in diverse tissues with adluminal simple epithelia, including salivary and other glandular epithelia, duct epithelia and pulmonary epithelium, bladder urothelium and the seminiferous and excurrent duct epithelia of the testis (cf. Domke et al. 2014). In bovine muzzle epithelial glands and ducts (Fig. 3), the marked striatin zonula immunostaining is seen in both the secretory and the ductal cells. Essentially identical results have been obtained in all five mammalian species examined.

As the polar organization of the hepatocytes in mammalian liver tissue represents an especially complex junction, and as liver physiology and diseases are of special importance, we have performed detailed double- and triple-label high-resolution immunolocalization reactions on cryostat liver sections of the five mammalian species used, namely mouse, rat, pig, cattle and human. Figure 4 presents the results obtained by double-label immunofluorescence microscopy, comparing the punctate, rather regularly spaced desmoplakin reaction sites along the bile canaliculi with the thin and distinct, but also intensive, striatin reaction of the apical zonula adhaerens structures (Fig. 4a-a", b-b"). Moreover in cross-sections through the bile canaliculi, we could demonstrate (Fig. 4cc") the entire subapical plasma membrane reaction of striatin in direct comparison with the surrounding desmosomes. These results were identical in all five species and were also similar to those obtained for other zonula adhaerens markers, including the proteins myozap (Rickelt et al. 2011) and LUMA (Franke et al. (2014).
Light microscopic immunolocalization in stratified epithelia

Epithelia of this category are characterized by variously sized and variously structured interdesmosomal regions that can be studded not only with "gap junctions", but also with single molecules or "islands" of TJ and/or AJ molecules ("tessellate junctions"; cf. Franke and Pape 2012; Franke et al. 2013). The patterns of these interdesmosomal cell-cell junction structures vary markedly not only between the various types of epithelia, but also in the various cell layers.

Punctate and fascia-like striatin immunolocalization reactions have also been noted in the various stratified epithelia examined. For example, the distribution of striatin-containing portions in tessellate junction layers of bovine tongue mucosa is shown in comparison with immunostaining for $\beta$-catenin in Fig. 5. In the interdesmosomal cell-cell contact regions of these stratified tissues, small punctate fascia-like or even more extended striatin reaction sites are often seen, mostly showing colocalization of AJ molecules with TJ markers such as occludin, because of spatial overlap. Moreover, in several stratified epithelia, striatin immunostaining is not restricted to colocalization areas with other AJ proteins but has selectively been noted in upper layers, positionally equivalent to the upper stratum spinosum and the granulosum layers of the epidermis, even in regions that appear totally negative for proteins including the catenins, p120, p0071 and protein ZO-1 (see Fig. 5, upper portion). The reactive structures and the intensities of the various members of the striatin protein family can differ in the different stratified epithelia, i.e. epidermis, oral and lingual mucosa regions, oesophagus, pharynx epithelium and stratified thymic reticulum epithelium ("Hassall bodies"). Therefore, we have decided to devote a special future article to the complex patterns of AJ protein localizations in the distinct substructures of tessellate junctions of mammalian stratified epithelia and in tumours and cell cultures derived therefrom.

Immunolocalization in myocardiac tissues

In view of the molecular architectonic, functional and medical importance of CJs in the intercalated disks, and in view of the special roles of such molecules in the pathogenesis of a series of heart diseases and "sudden death" forms, we have carefully examined and compared the five mammalian species mentioned by immunofluorescence microscopy. Moreover, as a single striatin polypeptide appeared to be the predominant, if not exclusive isoform in myocardiac cells in situ (see Fig. 1a, c'), we made certain, in all cases, that the antibodies specific for this striatin were included in the experiments.

As shown for the example of boar heart (Fig. 6), striatin is highly enriched in the CJs, usually showing colocalization with N-cadherin and $\beta$-catenin (Fig. 6a-a", b-b"') and with p120, desmoplakin, plakophilin-2 and desmoglein-2 (Dsg2; 

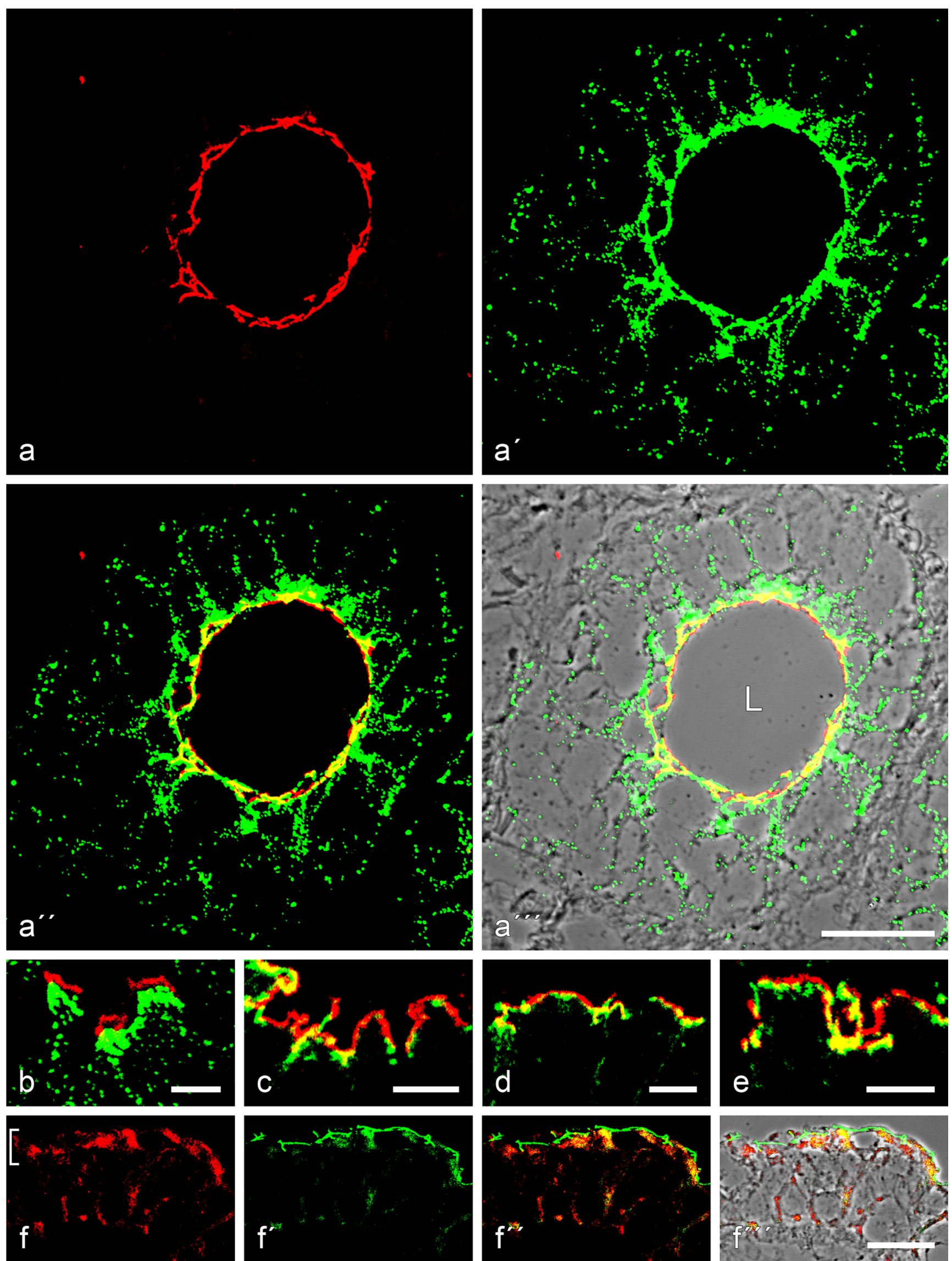
4 Fig. 2 Immunolocalization of striatin in the zonula adhaerens of bovine intestinal epithelial cells. a-a"" Double-label confocal laser scanning immunofluorescence microscopy, showing striatin (a, red; mAb mouse $[\mathrm{m}])$ in a relatively narrow apical zone in partial colour reaction overlap with desmoplakin (a', green; pAb gp). This double-label immunoreaction is seen in a" and on a phase contrast background in a"'. Note, however, that striatin is restricted to the subapical ring (zonula adhaerens; L, lumen), whereas desmoplakin is also located in the numerous desmosomes of the basolateral cell-cell contacts. b Higher resolution micrograph showing the distinct separation of the striatin-positive zonula (red) and the basolateral desmosomes (green). c-e Differential immunostaining reactions of striatin (red; $\mathrm{mAb} \mathrm{m}$ ) and $\beta$-catenin (green; rabbit [rb] antibody), indicative of zones of colocalization (yellow) and local segregation (red). f-f," Double-label immunofluorescence microscopy showing the same tissue after localization of proteins PERP (f, f", f'", red; $\mathrm{mAb}$ m) and striatin (f'-f'", green; gp). Note that striatin is restricted to a thin upper line of the zonula adhaerens (green), whereas protein PERP is seen in a slightly lower zone and in special larger punctate structures both at the zonula and at the basolateral membranes (bracket and bottom in f, respectively). Bars $20 \mu \mathrm{m}(\mathbf{a}, \mathbf{f}), 5 \mu \mathrm{m}(\mathbf{b}-\mathbf{e})$ not shown). Essentially identical colocalization results have been obtained for bovine cardiomyocytes in situ (Fig. 7a-a"" presents, for example, colocalization with desmoplakin). Several other AJ plaque proteins such as ZO-1 also colocalize with striatin in CJs but here striatin label has not been detected in the zonulae adhaerentes of the interspersed blood capillaries (Fig. 7b, b').

Colocalization of striatin with other CJ molecules has also been found in a significant proportion of the junctions of the Purkinje network of conducting cells (Fig. 7c-c"; for an extensive recent review of cardiac conduction cells, see Mezzano et al. 2014). In addition, we have noted, in the conductive cells, a few striatin-positive junctional reaction sites that are negative for all desmosome-specific marker proteins and other junctions that are desmoplakin- and plakophilin-2-positive but negative for all striatin antibodies tested (not shown).

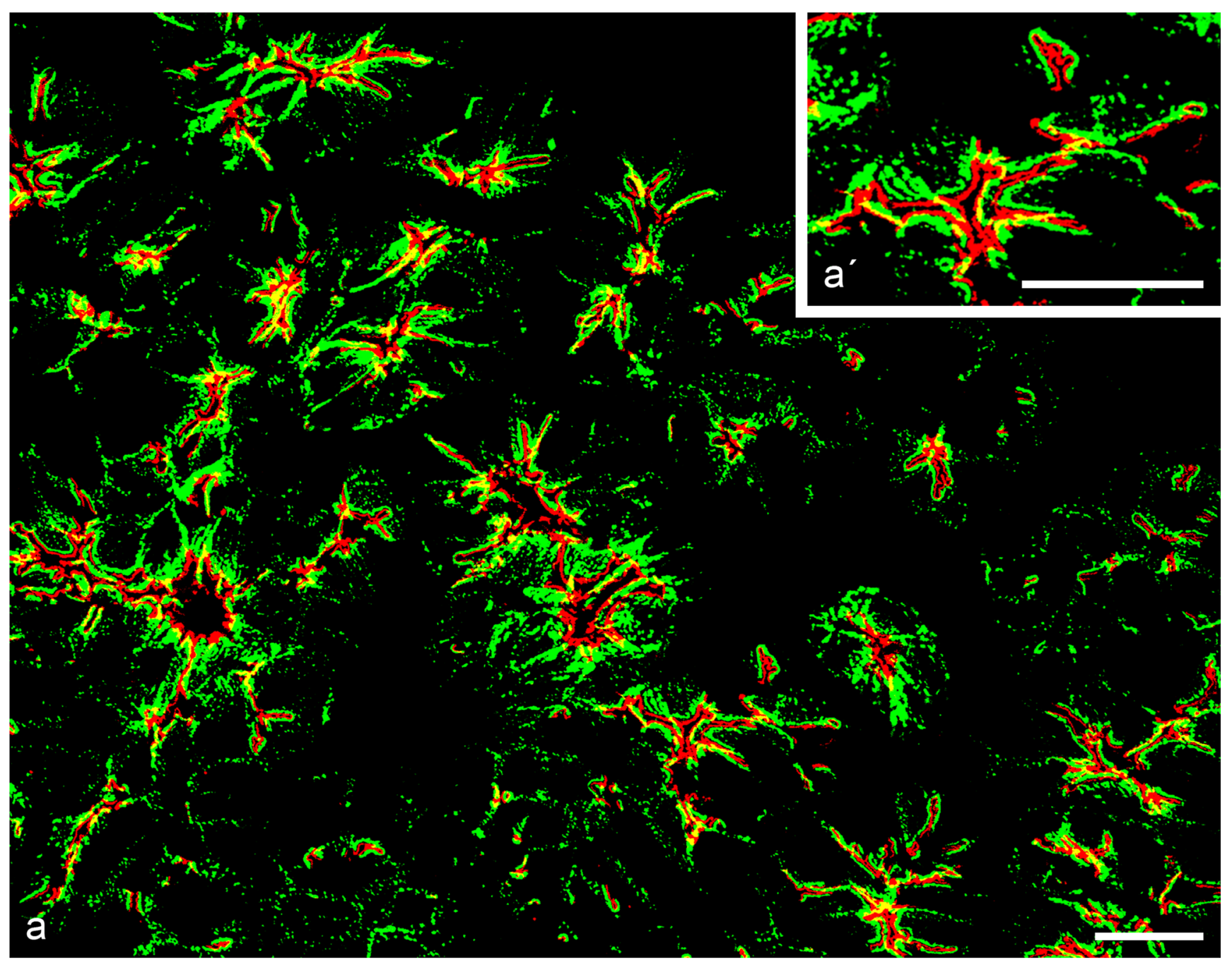

Fig. 3 Double-label confocal laser-scanning immunofluorescence microscopy of cryostat sections through a bovine muzzle epidermis region rich in glandular and ductal epithelium. a Survey of cross- or obliquely-sectioned gland structures showing the general frequency of desmosomes (green; desmoplakin, gp antibody) and zonulae adhaerentes positive for striatin (red; $\mathrm{mAb} \mathrm{m})$. a' Higher magnification illustrating the differential localization of these two structures. Bars $20 \mu \mathrm{m}$ 

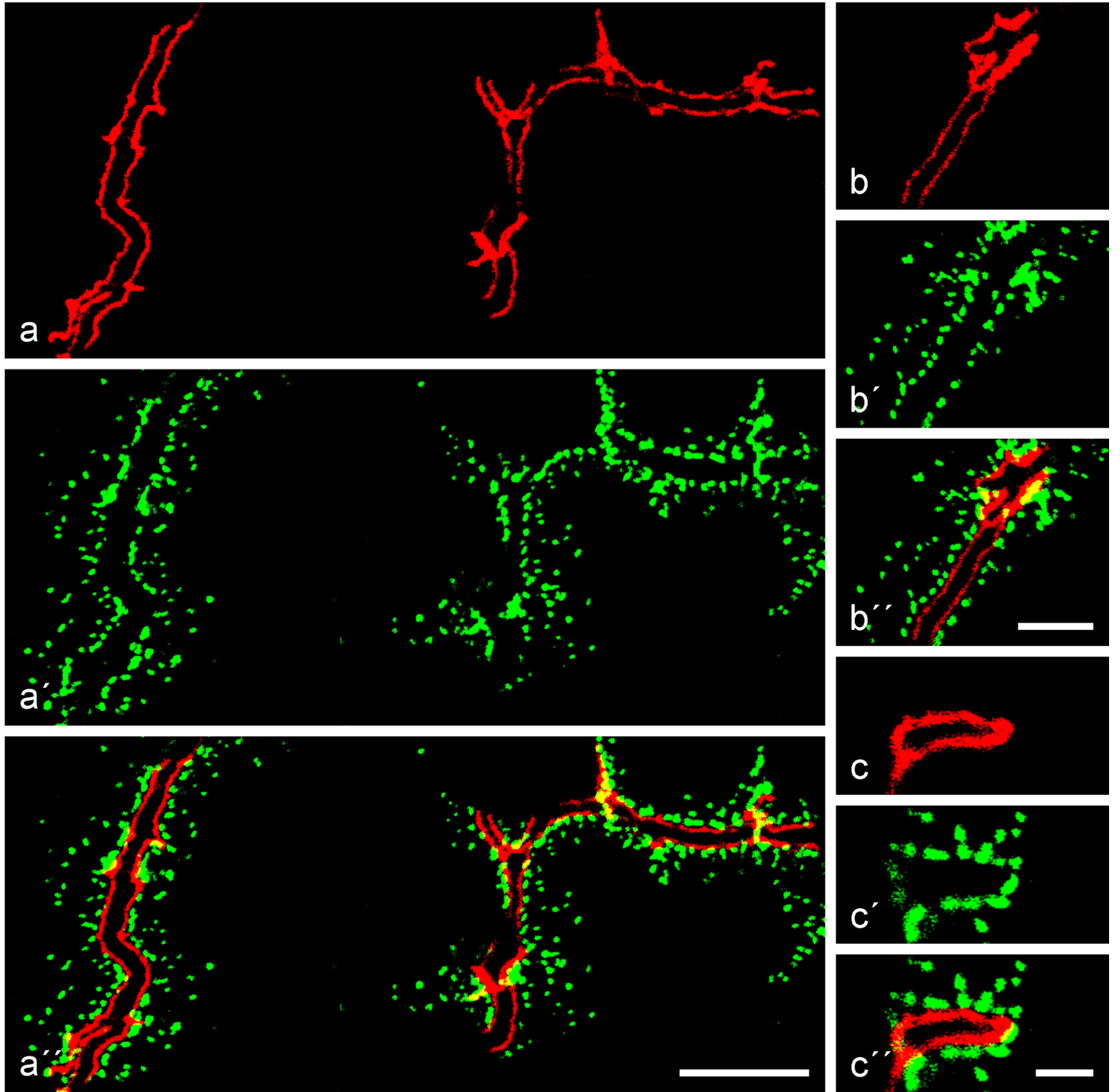

Fig. 4 Specific immunolocalization of striatin in the zonula adhaerens structures of hepatocytes extending along the bile canalicular surface in bovine liver tissue. a-a" Double-label confocal laser scanning immunofluorescence microscopy of near-longitudinal sections of bile canaliculi, showing the location of striatin (a, red; $\mathrm{mAb} \mathrm{m})$ in comparison with the strictly desmosomal position of desmoplakin (a', green; pAb gp). Note that in double-colour labelling (a"), the reaction of "free" desmosomes is strictly green, indicating that the desmosomes do

In both murine species examined, the colocalization of striatin with $\beta$-catenin (Fig. 8a-a""), p120 and p0071 and with desmoglein-2, desmoplakin, plakophilin-2 and plakoglobin have also been observed. However, in a number of experiments, we have also detected small ("dot-like") cytoplasmic reaction sites that are positive only for striatin or only for not contain any striatin. b-b" Same preparation as in $\mathbf{a}-\mathbf{a}$ " showing that, for most of the section, an unstained space of the canalicular lumen is seen between the striatin-rich layer of the zonula (red) and the desmoplakinpositive desmosomes (b', b", green). c-c" Same preparation showing a near exact cross-section through a bile canaliculus surrounded by a continuous striatin-positive zonula (red) and a series of desmoplakinpositive desmosomes (c', c", green). Bars $10 \mu \mathrm{m}$ (a), $5 \mu \mathrm{m}$ (b), $2.5 \mu \mathrm{m}$ (c)

specific CJ partner molecules such as $\beta$-catenin (see Electronic supplementary material, Fig. S5), p120 and p0071 or $\alpha$ catenin (not shown).

Unsurprisingly, the same kind of results were also obtained in our extensive localization studies of human myocardium. As shown in cross-sections of intercalated disks (Fig. 8a-a", c) 

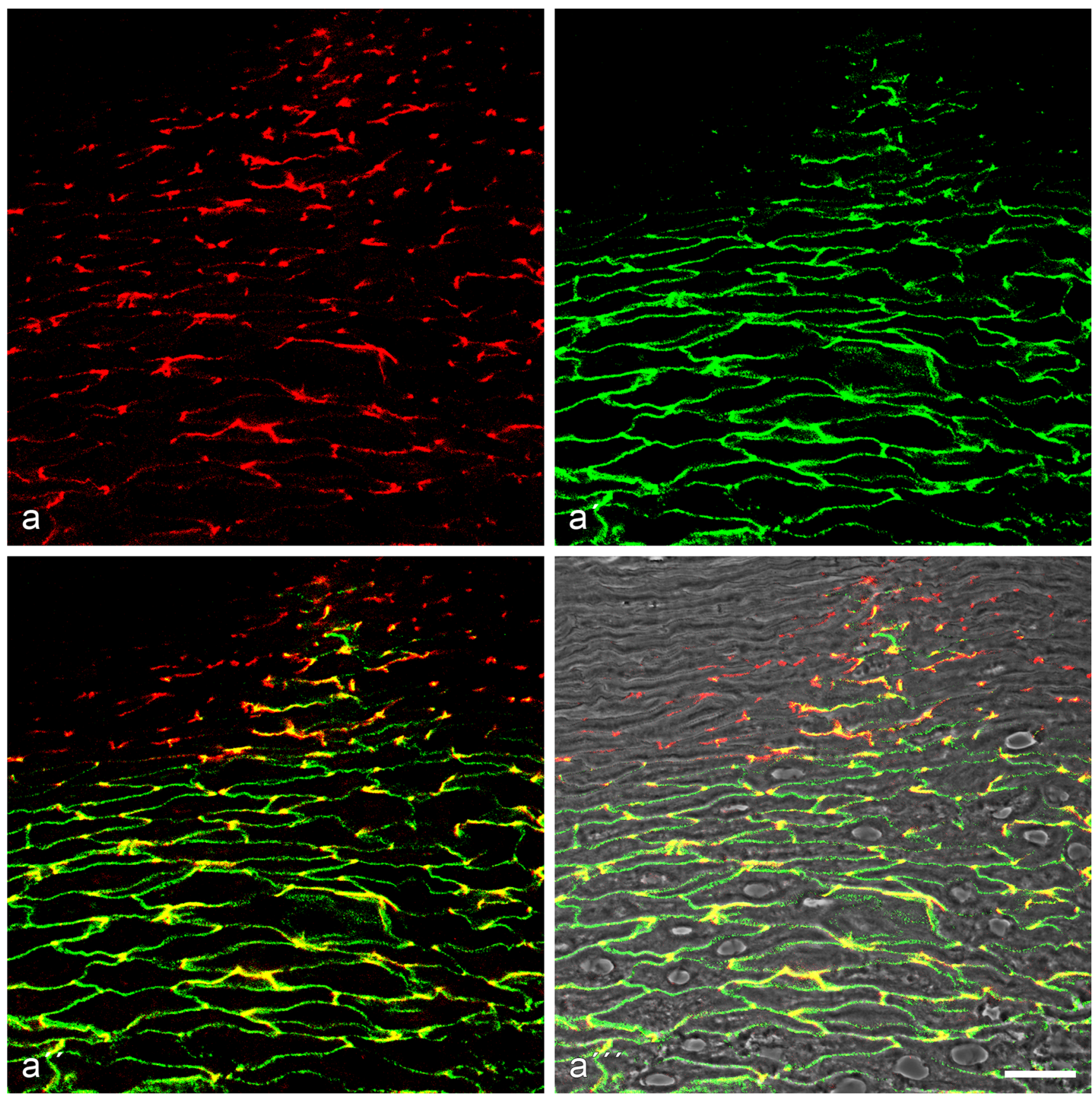

Fig. 5 Double-label confocal laser scanning immunofluorescence microscopy showing one of the subforms of cell-cell tessellate junctions in a multistratified epithelium, namely the ventral part of bovine tongue mucosa. a-a" Striatin (red; $\mathrm{mAb} \mathrm{m}$ ) demonstration in regional

and in grazing-horizontal sections of intercalated disks (Fig. 8b-b"'), pronounced colocalization was typical for at least one isoform of striatins with N-cadherin (Fig. 8a-a"', bb"'), $\beta$-catenin, p120 and p0071 (not shown) and with desmoplakin (Fig. 8c), desmoglein Dsg2, plakophilin-2 and plakoglobin (not shown). In special control experiments, we also used two different types of striatin antibodies, namely, one that cross-reacted with various striatins and one that substructures, including polar or fascia-like tessellate junctions; the $\beta$ catenin-positive portion (green; pAb gp) of the tessellate junctions extends over much larger cell-cell contact areas. Bar $20 \mu \mathrm{m}$

reacted only with the major cardiac striatin polypeptide. Again, near-complete colocalization was observed (Fig. 8d).

Colocalization of striatin(s) in the plaques of CJs has also been found for plectin, an extremely large protein previously described in association with various other contractile and cytoskeletal proteins (Wiche et al. 1983; Wiche 1989; Andrä et al. 1997; for biochemical data, see also Wiche et al. 1982; Pieperhoff et al. 2012) and 

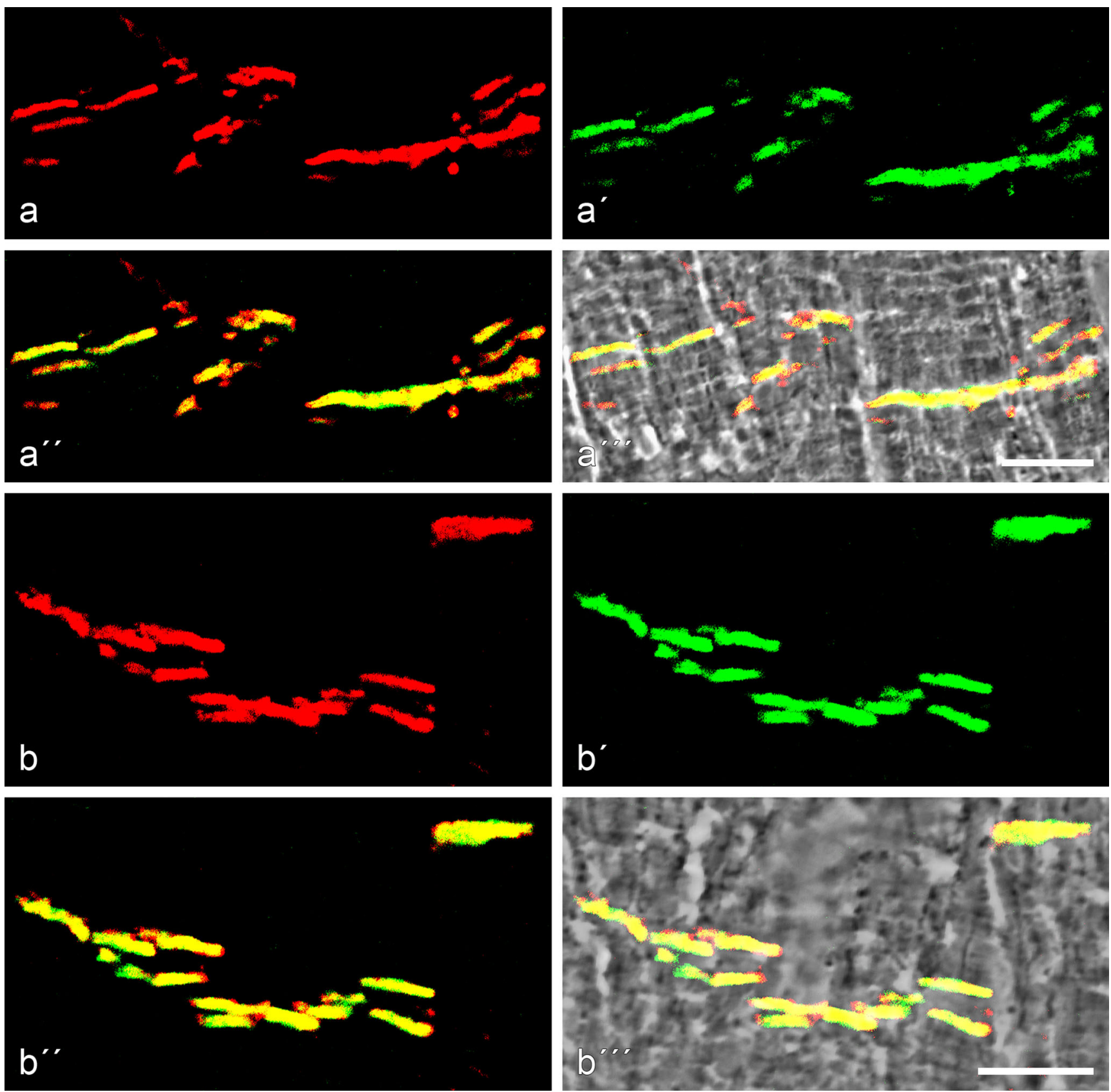

Fig. 6 Double-label confocal laser scanning immunofluorescence microscopy of cryostat sections through porcine (boar) myocardium. aa" Immunostaining of striatin in the complete composite junctions (areae compositae) of the intercalated disks (a', green; pAb gp) in comparison with $\beta$-catenin (a, red, $\mathrm{mAb} \mathrm{m})$, showing extensive colocalization (a", yellow merged colour; a", as a", but with a phase

ankyrin-G (Electronic supplementary material, Fig. S6), confirming the data of Makara et al. (2014; see also Mohler et al. 2004; Sato et al. 2011; for a review, see Bennett and Healy 2009). To demonstrate the specificity and intensity of the binding of ankyrin-G and plectin to other CJ plaque proteins and, notably, also to the protein myozap (see also Pieperhoff et al. 2012) and striatin (Fig. S6f), gradual "buffer wash treatments" of cryostat

contrast background). b-b" Parallel preparation to that of a-a" " but after reactions with antibodies to $\mathrm{N}$-cadherin $(\mathbf{b}, \mathrm{red} ; \mathrm{mAb} \mathrm{m})$ and to striatin (b', green; pAb, gp), again showing colocalization (yellow merged colour) without (b") and with (b"') phase contrast background. Bars $10 \mu \mathrm{m}$

sections have been regularly performed (see also previous sections).

Light microscopic immunolocalization of striatin in cultured epithelial and myocardiac cells

Localization studies of striatin with $\alpha$ - and $\beta$-catenin, with other AJ markers and with desmosomal molecules 

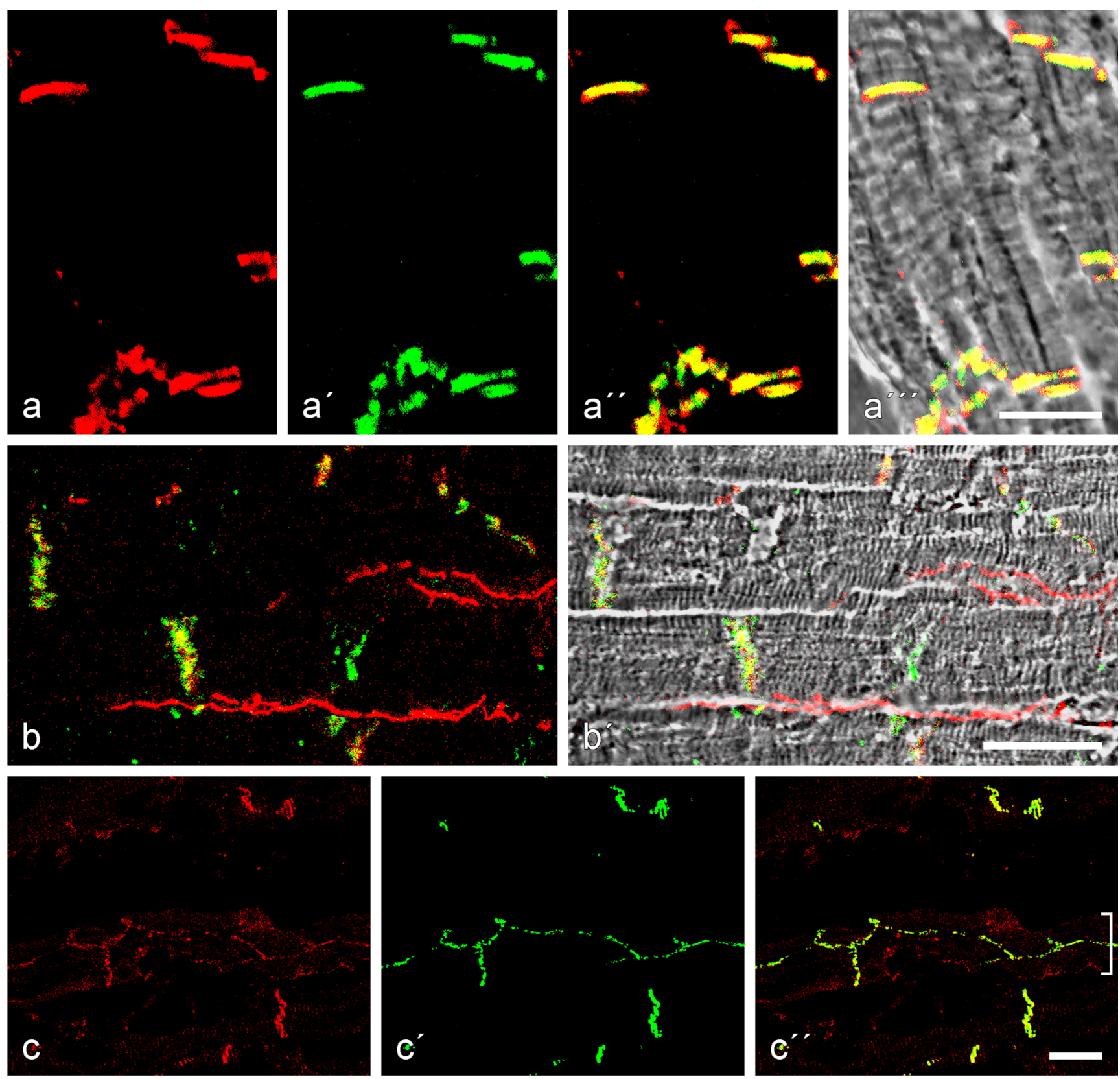

Fig. 7 Double-label confocal laser scanning immunofluorescence microscopy of cryostat sections through bovine myocardium. a-a"" Immunostaining of desmoplakin $(\mathbf{a}, \mathrm{red}, \mathrm{mAb} \mathrm{m})$ compared with that of striatin (a', green; pAb gp) shows extensive colocalization (yellow merged colour in a" without and in a" with phase contrast background). Note also some small but distinct punctate staining regions that are either red, i.e. positive for desmoplakin, or green, i.e. positive for striatin. $\mathbf{b}, \mathbf{b}$ ' Double-labelling with antibodies to the plaque protein ZO-1 (b, red; $\mathrm{mAb} \mathrm{m})$ in comparison with antibodies to striatin

(b, green; pAb gp) shows colocalization in the composite junctions but exclusive protein ZO-1 labelling at the junctions of the cardiac capillary endothelium (red). The relationship to the specific structures is seen in the phase contrast background image (b'). Note also some small strictly red or green punctate structures. c-c" Double-labelling immunostaining of striatin (c, red; $\mathrm{mAb} \mathrm{m}$ ) and desmoplakin (c', green; $\mathrm{pAb}$ gp) in $\mathbf{c}$ " shows that the conductive cells of the Purkinje cell system also contain some junctions that appear yellow (merged colour in c", bracket). Bars $20 \mu \mathrm{m}$

have also been performed on cell culture monolayers, including epithelium or carcinoma-derived cells and cardiomyocyte-derived cells (for biochemical demonstrations of the presence of striatins in such cells, see Fig. 1a, b and Electronic supplementary material, Fig. S1; for immunofluorescence microscopy, see

Electronic supplementary material, Figs. S7-S10). Striatins have been identified as major components not only in the cell-cell connecting zonulae adhaerentes of primary cultures. Figure S7, for example, shows a monolayer culture of rat myocardiac cells taken 2 days after birth (cf. Pieperhoff et al. 2012). This micrograph 

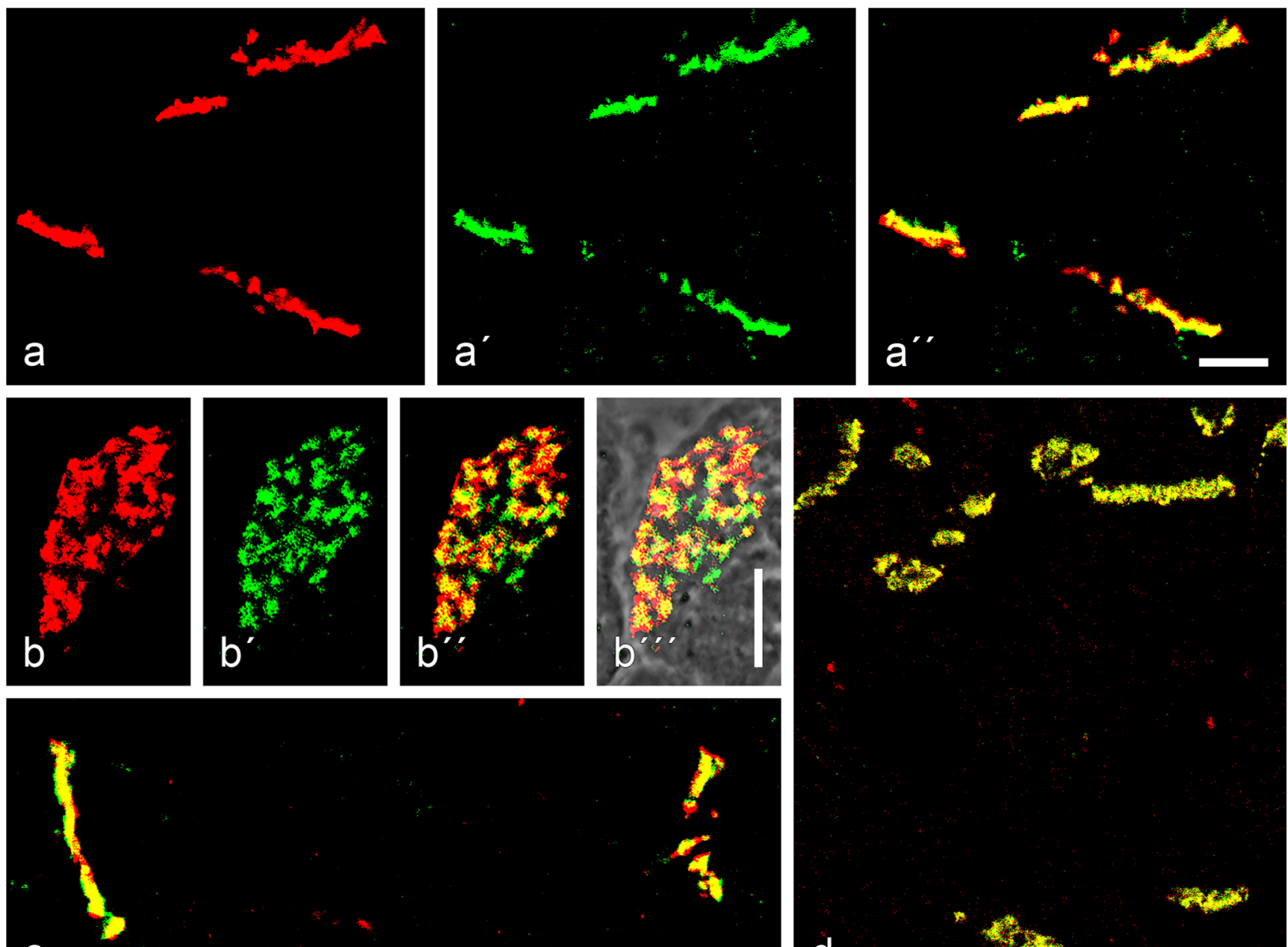

C
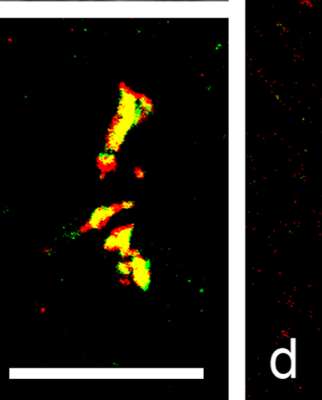

of striatin (green; $\mathrm{pAb} \mathrm{gp}$ ) with desmoplakin ( $\mathrm{red} ; \mathrm{mAb} \mathrm{m}$ ) in the plaques

Fig. 8 Double-label confocal laser scanning immunofluorescence microscopy of cryostat sections through human myocardium. a-a" Colocalization of $\mathrm{N}$-cadherin (a, red; $\mathrm{mAb} \mathrm{m})$ and striatin (a', green; $\mathrm{pAb} g \mathrm{p}$ ) on cross-sections of composite junctions (a", yellow merged colour). Note, however, the occurrence of some small isolated punctate striatin-positive, i.e. green, reaction sites (e.g. in the middle between the two composite junctions in the lower part of the image). b-b" Colocalization (reagents as in $\mathbf{a}-\mathbf{a}$ ") of N-cadherin (b) and striatin (b') on near-horizontal sections of intercalated disks (b", b" merged images, presented in b"' on a phase contrast background). Note the yellow merged colour in each of the composite junction substructures. c Colocalization of composite junctions. Note also a tiny punctate and exclusively desmoplakin-positive reaction site (middle bottom). d Control of the colocalization approach by using two different antibodies reactive with striatin: $\mathrm{mAb}(\mathrm{m})$ reactive with different striatins (red) and pAb (gp) reactive only with a specific striatin type (green). The colocalization (yellow merged colour) shows that striatin 3 is predominant and that no other striatin is recognized in the myocardium (note the tiny "artificial" red dot in the centre of the region right serving as a control). Bars $10 \mu \mathrm{m}$ $(\mathbf{a}, \mathbf{b}), 20 \mu \mathrm{m}(\mathbf{c}, \mathbf{d})$

also demonstrates the absence of striatin in certain desmosome-related structures, including the variously sized intracellular assemblies of desmoplakin-rich material. Striatin has also been seen in continually-appearing cell-cell contact AJs of all epithelial cell culture monolayers examined (Figs. S8-10 present examples of the human breast carcinoma line MCF-7). Thus, striatins have to be counted among the obligatory constituents of AJs in tissues and in cell cultures. As striatins also occur in single cells in culture and in the living mammalian body (see Fig. 1 and Electronic supplementary material, Figs. S6-S9), one has to conclude that the synthesis and stability of striatin(s) are not dependent on established cell-cell junctions.

Remarkably, the integration of striatin(s) into the AJ zonula plaque structures is not restricted to completed assembly at the cell-cell contacts but can be detected in small puncta- or fascia-like structures in the cytoplasm, even in juxtanuclear regions, or in short plasma membrane intercepts before the formation of a continuous zonula adhaerens (Figs. S8, S9). In such situations, we find it especially surprising that even the 
Fig. 9 Immunoelectron microscopic localization of striatins in cytoplasmic plaques of adherens junctions in a simple epithelial tissue and an epithelium-derived cell culture. a-c Silver-enhanced immunogold reactions on ultracryotome sections of bovine liver tissue, showing that striatins are components of the adherens junction plaques in the interdesmosomal regions connecting here three (a) or four (b) hepatocytes $(H)$, whereas desmosomes $(D$ in $\mathbf{c})$ are negative. $\mathbf{d}$ The specificity of adherens junctions is also evident from their localization in the entire subapical zonula adhaerens surrounding the bile canaliculi $(B C)$. Note that, in the intracanalicular space, the villuslike apical cell processes are negative. e, f Silver-enhanced immunogold reaction of striatin antibodies in the entire adherens junction region between the desmosomes $(D)$ in a monolayer cell culture of human breastcarcinoma-derived MCF-7 cells (IF bundles of intermediate-sized filaments). Note in $\mathbf{b}$ that the striatin label is exclusively seen in the submembranous plaque. Bars $2 \mu \mathrm{m}$ (b), $1 \mu \mathrm{m}$ (a), $500 \mathrm{~nm}$ (c-e), $200 \mathrm{~nm}$ (f)
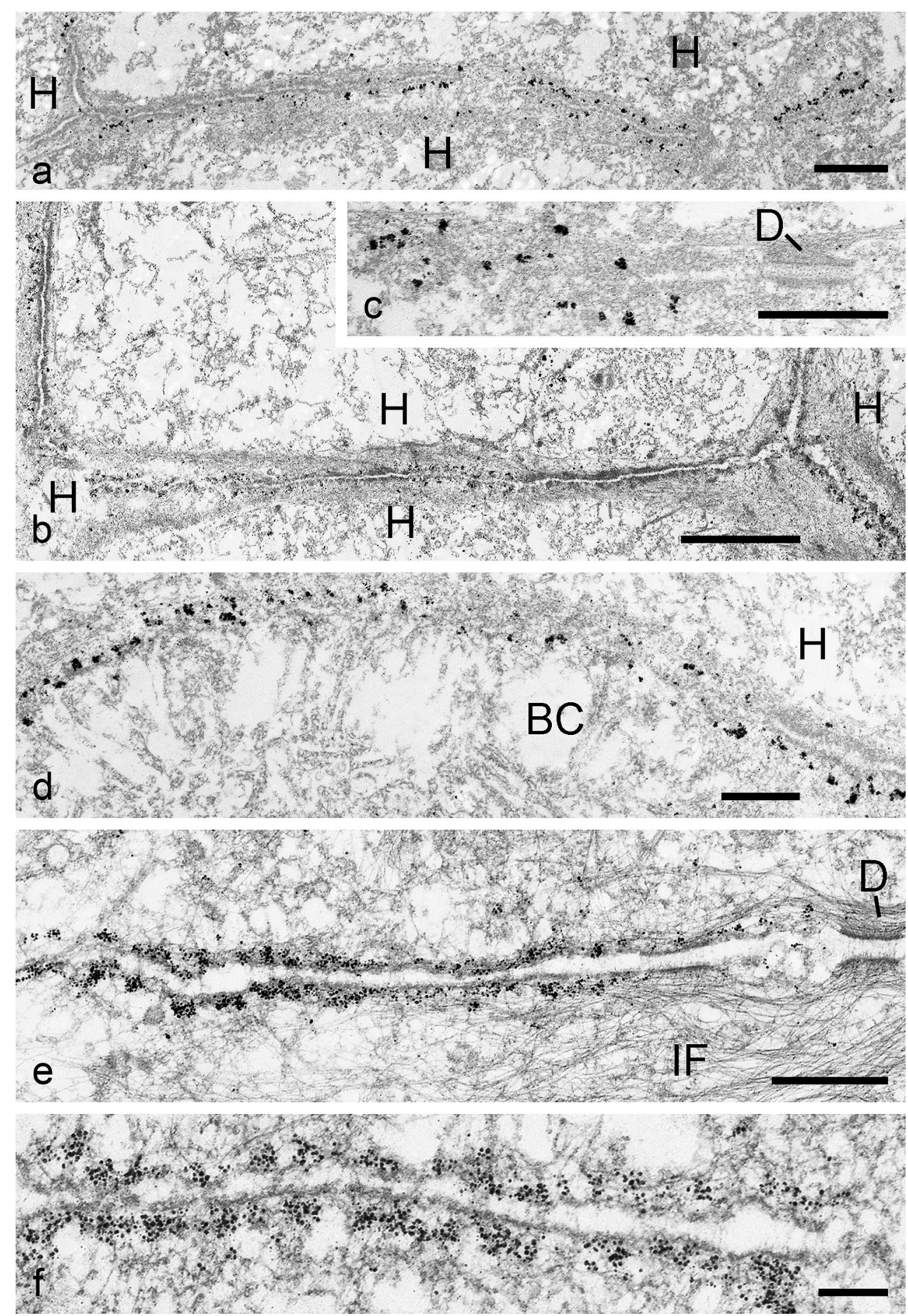

newly formed AJ molecules are often closely associated with TJ proteins such as claudins and/or occludin (Figs. S8-S10).

Immunoelectron microscopic localizations of striatins

Using snap-frozen tissues or monolayer cell cultures, we have been able to localize specific striatins on the plaques of cell- cell contact regions of the $\mathrm{AJ}$ type, as is shown for bovine liver tissue in Fig. 9a, b. Again, desmosomes or other categories of junctions (gap junctions, TJs) are not immunogold-labelled at all (e.g. the junction labelled D in Fig. 9c). Moreover, the immunogold reaction sites are all associated with cytoplasmic plaques of AJ strucures. Particularly eye-catching in this tissue is the zonula adhaerens labelling extending over the subapical junction region bordering on the bile canaliculi (BC in 


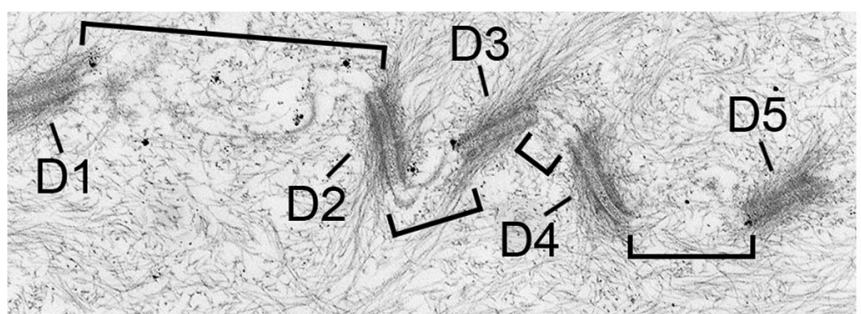

a
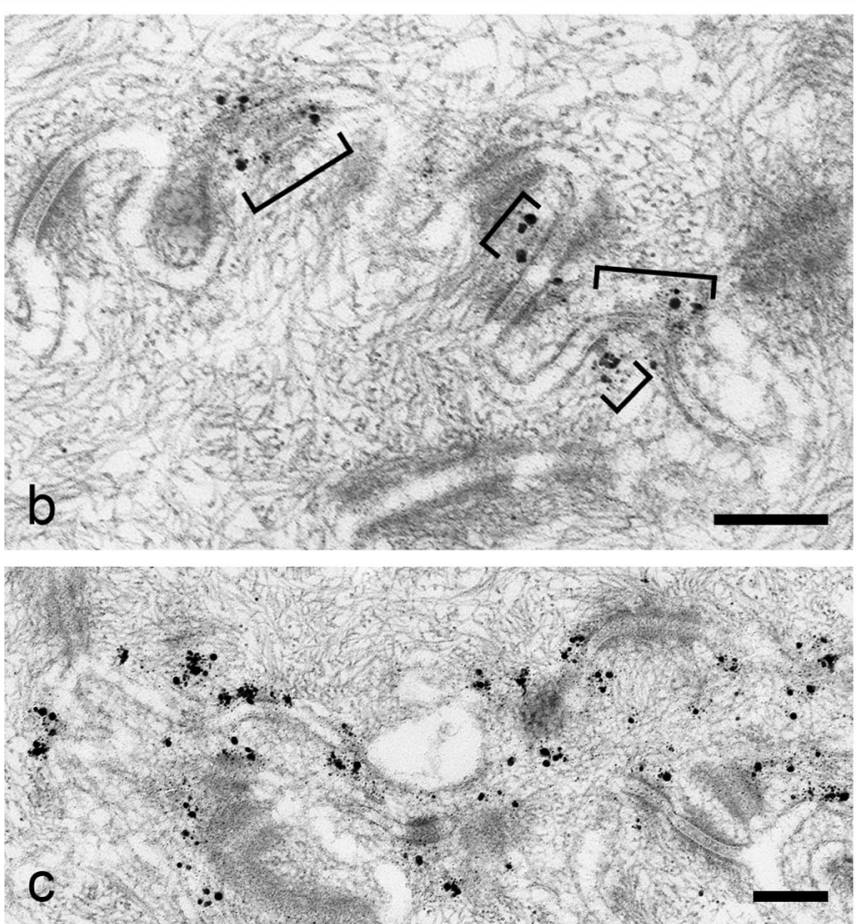

Fig. 10 Immunoelectron microscopic localization of striatins in small punctum- or fascia-like adherens junctions or "molecular islands" in the interdesmosomal regions of the tessellate junctions of a stratified epithelium (here, bovine tongue mucosa). a-c Silver-enhanced immunogold reaction sites of antibodies against striatins on cryotome sections through bovine tongue mucosa fixed and embedded as described and further sectioned into ultrathin sections. The exposure times to striatin antibodies in the samples shown were 5, 7 and 9 min, respectively. a Survey micrograph showing the small original reaction sites (dots gold grains) in the interdesmosomal regions (D1-D5 desmosomes, brackets tessellate junction regions). Note the abundance of bundles of intermediate-sized filaments (IFs) of the keratin type in the cytoplasm. b As in a, more than seven desmosomes occur in this region, with

Fig. 9d), whereas no striatin label is associated with the apical villus-like cytoplasmic processes extending into the bile canalicular interior.

Even more extended and often dense immunolocalization reaction products have been seen in the plaques of interdesmosomal AJ-type cell-cell contact regions of densely grown monolayers of human breast carcinoma MCF-7 cells (Fig. 9e, f), hepatocellular carcinoma PLC and colon carcinoma $\mathrm{CaCo} 2$ cells (not shown) and in human epidermis-derived $\mathrm{HaCaT}$ tumour cells (not shown). Here, large amounts of antibody-bound heavy
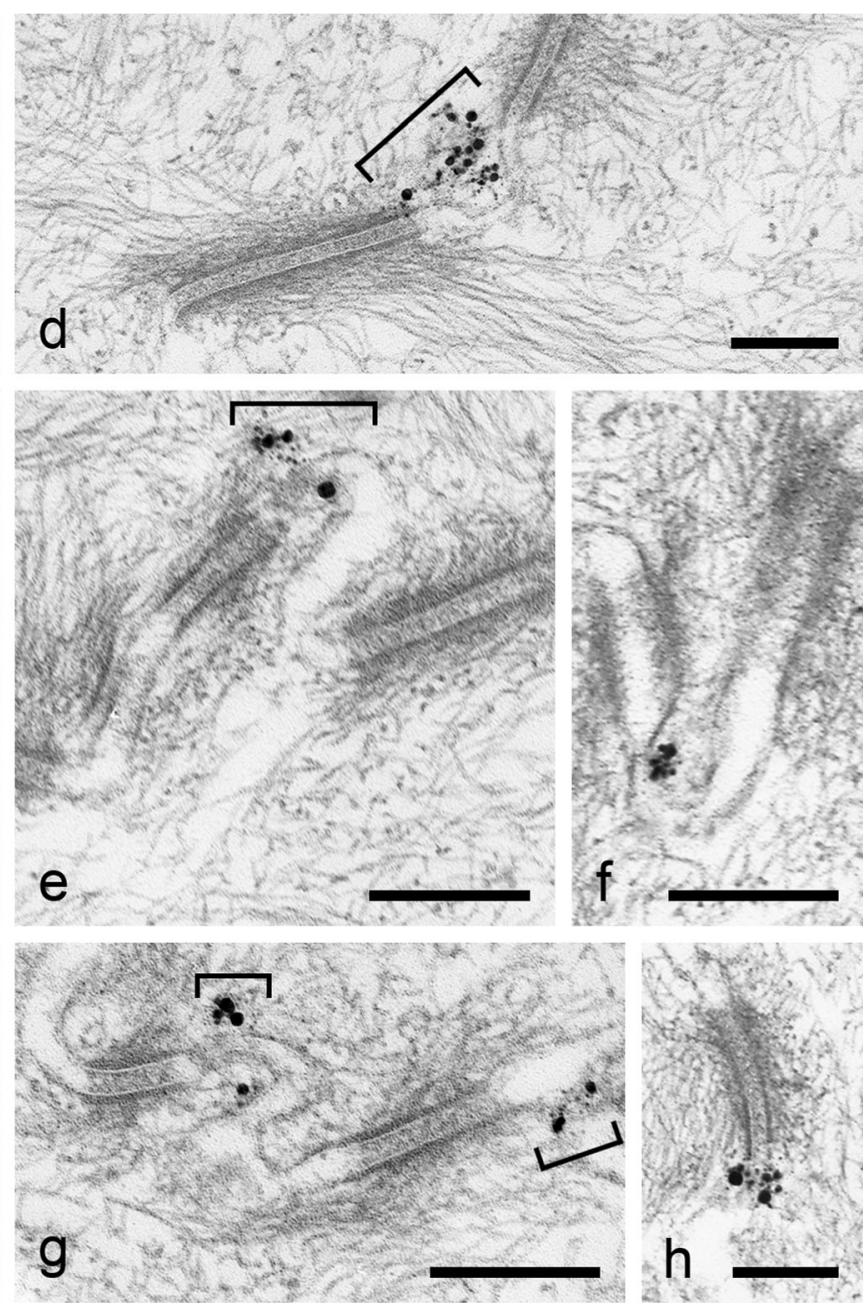

relatively high label densities (brackets) in variously sized and variously positioned interdesmosomal cell-cell contact regions. c Higher label densities showing the confinement of the striatin reaction sites to interdesmosomal regions. d Higher magnification showing an intensely immunogold-labelled junction cluster in an interdesmosomal tessellate junction region. e Higher magnification revealing a cluster of both small and larger heavy metal grains of a striatin reaction in a small punctum adhaerens-like junction island. $\mathbf{f}-\mathbf{h}$ Striatin cluster (bottom in $\mathbf{f}$ ) next to the edge of a desmosome (f), small interdesmosomal islands of immunolabelled puncta adhaerentia (brackets), and a striatin-rich cellcell contact island (bottom in $\mathbf{h}$ ) in direct association with the margin of a desmosome. Bars $200 \mathrm{~nm}$

metal grains are exclusively concentrated on the submembranous AJ plaques (see Fig. 9f), whereas neither gap junctions nor TJs show marked enrichment.

In stratified epithelia, immunoelectron reaction is also restricted to interdesmosomal regions. Figure 10a-h shows striatin labelling by gold-silver grains at such regions (desmosomes are numbered in Fig. 10a) with only a few small immunogold grains. By contrast, Fig. 10b presents clusters of larger metal label grains in positions that, in some cases, might be equivalent to local puncta adhaerentia within a tessellate junction (regions denoted by brackets in 
Table 2 Constitutive molecules of composite junctions (areae compositae) in the intercalated disks of mammalian cardiomyocytes

\begin{tabular}{ll}
\hline $\begin{array}{l}\text { Transmembrane cadherins } \\
\text { Adherens junction molecules } \\
\text { N-cadherin }\end{array}$ & $\begin{array}{l}\text { Plaque proteins } \\
\text { Adherens junction molecules } \\
\text { Cadherin-11 }\end{array}$ \\
& $\frac{\beta \text {-Catenin }(\alpha \mathrm{E}+\alpha \mathrm{T})}{\text { Protein } \mathrm{p} 120}$ \\
& $\frac{\text { Protein } \mathrm{p} 0071}{\text { Protein ARVCF }}$ \\
& $\frac{\text { Plakoglobin }}{\text { Myozap }}$ \\
& Striatin(s) \\
Desmosomal molecules & Protein ZO-1 \\
Desmoglein 2 (Dsg2) & Desmosomal plaque molecules \\
Desmocollin 2 (Dsc2) & $\frac{\text { Plakoglobin }}{\text { Plakophilin 2 (Pkp2) }}$ \\
Other molecules & Desmoplakin \\
Plectin & \\
Ankyrin-G & \\
Protein PERP & \\
Protein LUMA & \\
\hline
\end{tabular}

Armadillo repeats-containing proteins are underlined

Fig. 10b). An even more extended and intensive interdesmosomal striatin labelling pattern is seen in Fig. 10c). In general, the sizes and the relative positions of striatin immunoreaction products vary (for light microscopic comparisons, see Electronic supplementary material, Fig. S5). In Fig. 10d, the label extends over the entire interdesmosomal region, whereas the antibody-linked heavy metal grains in Fig. 10e-h show a higher tendency to cluster in regions near desmosome margins. In view of the frequent close vicinity of striatin localization sites with desmosomal margins (see above), we have examined the proteins of desmosomal fractions from calf muzzle epidermis, tongue mucosa and oesophagus tissue prepared in the Heidelberg laboratory (see Mueller and Franke 1983; Kapprell et al. 1985) by SDS-PAGE and immunoblotting, with and without immunoprecipitation and protein cross-linking experiments (cf. Straub et al. 2011; Pieperhoff et al. 2012) but we have found no indications of the occurrence of striatins within desmosomal structures.

\section{Discussion}

Members of the striatin family of proteins are by no means specific for, or especially abundant in, neuronal or other cells of the nervous system as originally reported (for references see Introduction). As shown in this study, they are synthesized and integrated into protein complexes, dispersed particles or plaques of cell junctions of most, if not all mammalian cells, in single cells and in cultured cells and cells of tissues (see also Hwang and Pallas 2013).

For the sake of clarity, we consider it important to emphasize that our results show that the classification of members of the striatin family as "desmosomal proteins" (Meurs et al. 2013) is not correct. We have not detected striatin(s) in any type of desmosome or desmosome-related structure. On the contrary, striatins are exclusive and constitutive components of AJs such as the zonulae adhaerentes of polar epithelia, of certain punctate or fascia-like substructures of the tessellate junctions in stratified epithelia, and of the CJs in the intercalated disks of mammalian heart (for the latter localization in boxer dog, see also Meurs et al. 2010). Consequently, striatins (certainly the major cardiac isoform) should be added to the diagnostic "control list" of markers for hereditary AC and DC damage (Table 2; cf. Asimaki et al. 2009).

Our results also clearly show that striatin proteins are not components of TJs, although they can often be seen in the vicinity of TJs. The most convincing argument for this conclusion is presented by the CJs of the myocardial intercalated disks from which TJ-specific molecules and structures are totally absent. Similarly convincing examples are provided by several cultured cells with large regions positive for striatins and other AJ molecules but negative for TJ markers.

Additional locations of members of this protein family might occur in which the striatins as scaffold proteins are masked by specific complex partner molecules. Indeed, the members of this protein family are typical scaffold proteins able to form not only oligomeric complexes, but also complex "multimodular" structures, including some involved in diverse signalling and regulatory functions (see Muro et al. 1995; Castets et al. 1996, 2000; Bartoli et al. 1998, 1999; Kachidian et al. 1998; Salin et al. 1998; Moreno et al. 2000, 2001; Baillat et al. 2001; Gaillard et al. 2001; Yu et al. 2001; Lu et al. 2004; Joshi-Mukherjee et al. 2008; Gordon et al. 2011; Chen et al. 2012; for a recent general review on scaffold proteins see Garbett and Bretscher 2014). Consequently, we now need to examine the possible occurrence of such striatinbinding proteins and striatin-typical functions in plaque complexes of, for example, epithelial AJs and myocardiac CJs. Similarly important are detailed experimental analyses, including gene knock-out studies, to determine which of the so highly related and so similarly sized striatin forms are involved in certain pathogenic conditions, such as the aforementioned cardiac AC and DC damage.

Whether the pathogenic effects of certain CJ molecule mutations on cardiomyopathies such as ACs or Brugada syndrome take place in junctions between cardiomyocytes or in any of the special junctions connecting the conductive Purkinje fibre cells (for details, see Pieperhoff et al. 2010; Mezzano et al. 2014) remains unclear. Also unknown is whether these effects are direct or indirect, e.g. by involving 
connexin 43 or connexin 40 of the intimately associated gap junctions or the Nav1.5 sodium ion channels, and decisive experimental results are needed. Such indirect reactions via other adjacent cell-cell contact structures have repeatedly been discussed by a series of authors (Oxford et al. 2007a, b, 2011; Sato et al. 2009, 2011; Cerrone et al. 2012, 2014; Delmar and Liang 2012; Gomes et al. 2012; Agullo-Pascual et al. 2013, 2014; Meens et al. 2013; Noorman et al. 2013; Cerrone and Delmar 2014; Lyon et al. 2014; Vreeker et al. 2014; for earlier references and general reviews, see also Saffitz 2007, 2011; Delmar and McKenna 2010; Delmar and Makita 2012; Murray 2012; Rickelt and Pieperhoff 2012; Rizzo et al. 2012a, b). Finally, we cannot yet exclude that both direct and indirect effects of the mutated or otherwise modified molecules contribute to the pathogenetic effects mentioned. One hope is that detailed studies of the animal pathogenesis examples and transgenic experimental possibilities (for some related references, see Table 3 in Rickelt and Pieperhoff 2012; see also Fox et al. 2007; Vatta et al. 2007) will help in elucidating the cardiomyopathic mechanisms involved.

The recognition of striatin as a multimodular scaffolding protein that occurs in the cytoplasmic plaques of various kinds of cell junctions has also to be discussed in comparison with other scaffolding plaque proteins such as protein ZO-1 of various tight and adherens junctions (AJs), as well as $\mathrm{AJ} \alpha$-catenin and the ERM protein-binding component EBP50 found at the actin microfilament associations with microvillar membranes (for a review, see Garbett and Bretscher 2014). Such scaffolding proteins can also form a diversity of other complexes located in other structures or regions in which they might be masked for certain cell-type-specific antibodies but do indeed bind to antibodies reactive with other epitopes on the same molecule. As a result, the same scaffolding protein might immunocytochemically appear positive in one structure but negative in another. Consequently, such selective masking of one conformational domain might result in completely negative immunolocalization sites of the same protein that is positive with other antibodies (see, for example, the results obtained for protein LUMA in the report of Franke et al. 2014).

Acknowledgments We are grateful to Heide Schumacher and Edeltraut Noffz who were a great help in all cell culture work, to Dr. Michael Rogers for reading and correcting the English language and to Eva Gundel for the careful assembly of the text of the manuscript.

Open Access This article is distributed under the terms of the Creative Commons Attribution License which permits any use, distribution, and reproduction in any medium, provided the original author(s) and the source are credited.

\section{References}

Agullo-Pascual E, Reid DY, Keegan S, Sidhu M, Fenyö D, Rothenberg E, Delmar M (2013) Super-resolution flourescence microscopy of the cardiac connexome reveals plakophilin-2 inside the connexin 43 plaque. Cardiovasc Res 100:231-240

Agullo-Pascual E, Cerrone M, Delmar M (2014) Arrhythmogenic cardiomyopathy and Brugada syndrome: diseases of the connexome. FEBS Lett 588:1322-1330

Andrä K, Lassmann H, Bittner R, Shorny S, Fässler R, Propst F, Wiche G (1997) Targeted inactivation of plectin reveals essential function in maintaining the integrity of skin, muscle, and heart cytoarchitecture. Genes Dev 11:3143-3156

Antoniades L, Tsatsopoulou A, Anastasakis A, Syrris P, Asimaki A, Panagiotakos D, Zambartas C, Stefanadis C, McKenna WJ, Protonotarios N (2006) Arrhythmogenic right ventricular cardiomyopathy caused by deletions in plakophilin-2 and plakoglobin (Naxos disease) in families from Greece and Cyprus: genotype-phenotype relations, diagnostic features and prognosis. Eur Heart J 27:2208 2216

Asimaki A, Tandri H, Huang H, Halushka MK, Gautam S, Basso C, Thiene G, Tsatsopoulou A, Protonotarios N, McKenna WJ, Calkins H, Saffitz JE (2009) A new diagnostic test for arrhythmogenic right ventricular cardiomyopathy. N Engl J Med 360:1075-1084

Baillat G, Moqrich A, Castets F, Baude A, Bailly Y, Benmerah A, Monneron A (2001) Molecular cloning and characterization of phocein, a protein found from the Golgi complex to dendritic spines. Mol Biol Cell 12:663-673

Bartoli M, Monneron A, Ladant D (1998) Interaction of calmodulin with striatin, a WD-repeat protein present in neuronal dendritic spines. J Biol Chem 273:22248-22253

Bartoli M, Ternaux J-P, Forni C, Partalier P, Salin P, Amalric M, Monneron A (1999) Down-regulation of striatin, a neuronal calmodulin-binding protein, impairs rat locomotor activity. J Neurobiol 40:234-243

Bennett V, Healy J (2009) Membrane domains based on ankyrin and spectrin associated with cell-cell interactions. Cold Spring Harb Perspect Biol 1:a003012

Bennett PM, Maggs AM, Baines AJ, Pinder JC (2006) The transitional junction: a new functional subcellular domain at the intercalated disc. Mol Biol Cell 17:2091-2100

Benoist M, Gaillard S, Castets F (2006) The striatin family: a new signaling platform in dendritic spines. J Physiol (Paris) 99:146-153

Bierkamp C, McLaughlin KJ, Schwarz H, Huber O, Kemler R (1996) Embryonic heart and skin defects in mice lacking plakoglobin. Dev Biol 180:780-785

Blondeau C, Gaillard S, Ternaux J-P, Monneron A, Baude A (2003) Expression and distribution of phocein and members of the striatin family in neurones of rat peripheral ganglia. Histochem Cell Biol 119:131-138

Bobik A (2012) Striatin-dependent membrane estrogen receptor signaling and vasoprotection by estrogens. Circulation 126:19411943

Boda-Heggemann J, Régnier-Vigouroux A, Franke WW (2009) Beyond vessels: occurrence and regional clustering of vascular endothelial (VE-)cadherin-containing junctions in non-endothelial cells. Cell Tissue Res 335:49-65

Borrmann CM, Mertens C, Schmidt A, Langbein L, Kuhn C, Franke WW (2000) Molecular diversity of plaques of epithelial adhering junctions. Ann NY Acad Sci 915:144-150

Borrmann CM, Grund C, Kuhn C, Hofmann I, Pieperhoff S, Franke WW (2006) The area composita of adhering junctions connecting heart muscle cells of vertebrates. II. Colocalizations of desmosomal and fascia adhaerens molecules in the intercalated disk. Eur J Cell Biol $85: 469-485$ 
Breitman M, Zilberberg A, Caspi M, Rosin-Arbesfeld R (2008) The armadillo repeat domain of the APC tumor suppressor protein interacts with striatin family members. Biochim Biophys Acta 1783:1792-1802

Castets F, Bartoli M, Barnier JV, Baillat G, Salin P, Moqrich A, Bourgeois JH-P, Denizot F, Rougon G, Calothy G, Monneron A (1996) A novel calmodulin-binding protein, belonging to the WD-repeat family, is localized in dendrites of a subset of CNS neurons. J Cell Biol 134:1051-1062

Castets F, Rakitina T, Gaillar S, Moqrich A, Mattei M-G, Monneron A (2000) Zinedin, SG2NA, and striatin are calmodulin-binding, WD repeat proteins principally expressed in the brain. J Biol Chem 275: 19970-19977

Cerrone M, Delmar M (2014) Desmosomes and the sodium channel complex: implications for arrhythmogenic cardiomyopathy and Brugada syndrome. Trends Cardiovasc Med 24:184-190

Cerrone M, Noorman M, Lin X, Chkourko H, Liang F-X, Nagel R van der, Hund T, Birchmeier W, Mohler P, Veen TA van, Rijen HV van, Delmar M (2012) Sodium current deficit and arrhythmogenesis in a murine model of plakophilin-2 haploinsufficiency. Cardiovasc Res 95:460-468

Cerrone M, Lin X, Zhang M, Agullo-Pascual E, Pfenniger A, Chkourko Gusky H, Novelli V, Kim C, Tirasawadichai T, Judge DP, Rothenberg E, Chen H-SV, Napolitano C, Priori SG, Delmar M (2014) Missense mutations in plakophilin-2 cause sodium current deficit and associate with a Brugada syndrome phenotype. Circulation 129:1092-1103

Chen YK, Chen CY, Hu HT, Hsueh YP (2012) CTTNBP2, but not CTTNBP2NL, regulates dendritic spinogenesis and synaptic distribution of the striatin-PP2A complex.Mol Biol Cell 23: 4383-4392

Delmar M, Liang FX (2012) Connexin43 and the regulation of intercalated disc function. Heart Rhythm 9:835-838

Delmar M, Makita N (2012) Cardiac connexins, mutations and arrhythmia. Curr Opin Cardiol 27:236-241

Delmar M, McKenna WJ (2010) The cardiac desmosome and arrhythmogenic cardiomyopathies: from gene to disease. Circ Res 107: $700-714$

Domke LM, Rickelt S, Dörflinger Y, Kuhn C, Winter-Simanowski S, Zimbelmann R, Rosin-Arbesfeld R, Heid H, Franke WW (2014) The cell-cell junctions of mammalian testes. I. The adhering junctions of the seminiferous tubule epithelium represent special differentiation structures. Cell Tissue Res 357:645-665

Farquhar MG, Palade GE (1963) Junctional complexes in various epithelia. J Cell Biol 17:375-412

Fox PR, Basso C, Thiene G, Maron BJ (2007) Spontaneous animal models. In: Marcus FI, Nava A, Thiene G (eds) Arrhythmogenic RV cardiomyopathy/dysplasia. Recent advances. Springer, Milan, pp 69-78

Franke WW (2009) Discovering the molecular components of intercellular junctions - a historical view. Cold Spring Harb Perspect Biol 1: a003061

Franke WW, Pape U-F (2012) Diverse types of junctions containing tight junction proteins in stratified mammalian epithelia. Ann NY Acad Sci 1257:152-157

Franke WW, Borrmann CM, Grund C, Pieperhoff S (2006) The area composita of adhering junctions connecting heart muscle cells of vertebrates. I. Molecular definition in intercalated disks of cardiomyocytes by immunoelectron microscopy of desmosomal proteins. Eur J Cell Biol 85:69-82

Franke WW, Heid H, Zimbelmann R, Kuhn C, Winter-Simanowski S, Dörflinger Y, Grund C, Rickelt S (2013) Transmembrane protein PERP is a component of tessellate junctions and of other junctional and non-junctional plasma membrane regions in diverse epithelial and epithelium-derived cells. Cell Tissue Res 353:99-115

Franke WW, Dörflinger Y, Kuhn C, Zimbelmann R, Winter-Simanowski S, Frey N, Heid H (2014) Protein LUMA is a cytoplasmic plaque constituent of various epithelial adherens junctions and the composite junctions of the myocardial intercalated disks: a unifying finding for cell biology and cardiology. Cell Tissue Res 357:159-172

Gaertner A, Klauke B, Stork I, Niehaus K, Niemann G, Gummert J, Milting H (2012) In vitro functional analyses of arrhythmogenic right ventricular cardiomyopathy-associated desmoglein-2missense variations. PLoS One 7:e47097

Gaillard S, Bartoli M, Castets F, Monneron A (2001) Striatin, a calmodulin-dependent scaffolding protein, directly binds caveolin1. FEBS Lett 508:49-52

Gaillard S, Bailly Y, Benoist M, Rakitina T, Kessler J-P, FronzaroliMolinières L, Dargent B, Castets F (2006) Targeting of proteins of the striatin family to dendritic spines: role of the coiled-coil domain. Traffic 7:74-84

Garbett D, Bretscher A (2014) The surprising dynamics of scaffolding proteins. Mol Biol Cell 25:2315-2319

Gehmlich K, Syrris P, Peskett E, Evans A, Ehler E, Asimaki A, Anastasakis A, Tsatsopoulou A, Vouliotis A-I, Stefanadis C, Saffitz JE, Protonotarios N, McKenna WJ (2011) Mechanistic insights into arrhythmogenic right ventricular cardiomyopathy caused by desmocollin-2 mutations. Cardiovasc Res 90:77-87

Gerull B, Heuser A, Wichter T, Paul M, Basson CT, McDermott DA, Lerman BB, Markowitz SM, Ellinor PT, MacRae CA, Peters S, Grossmann KS, Drenckhahn J, Michely B, Sasse-Klaassen S, Birchmeier W, Dietz R, Breithardt G, Schulze-Bahr E, Thierfelder L (2004) Mutations in the desmosomal protein plakophilin-2 are common in arrhythmogenic right ventricular cardiomyopathy. Nat Genet 36:1162-1164

Gomes J, Finlay M, Ahmed AK, Ciaccio EJ, Asimaki A, Saffitz JE, Quarta G, Nobles M, Syrris P, Chaubey S, McKenna WJ, Tinker A, Lambiase PD (2012) Electrophysiological abnormalities precede overt structural changes in arrhythmogenic right ventricular cardiomyopathy due to mutations in desmoplakin - a combined murine and human study. Eur Heart J 33:1942-1953

Gordon J, Hwang J, Carrier KJ, Jones CA, Kern QL, Moreno CS, Karas RH, Pallas DC (2011) Protein phosphatase 2a (PP2A) binds within the oligomerization domain of striatin and regulates the phosphorylation and activation of the mammalian Ste20-Like kinase Mst3. BMC Biochem 12:54

Goudreault M, D'Ambrosio LM, Kean MJ, Mullin MJ, Larsen BG, Sanchez A, Chaudhry S, Chen GI, Sicheri F, Nesvizhskii AI, Aebersold R, Raught B, Gingras A-C (2009) A PP2A phosphatase high density interaction network identifies a novel striatininteracting phosphatase and kinase complex linked to the cerebral cavernous malformation 3 (CCM3) protein. Mol Cell Proteom 8: $157-171$

Grossmann KS, Grund C, Huelsken J, Behrend M, Erdmann B, Franke WW, Birchmeier W (2004) Requirement of plakophilin 2 for heart morphogenesis and cardiac junction formation. J Cell Biol 167:149 160

Heuser A, Plovie ER, Ellinor PT, Grossmann KS, Shin JT, Wichter T, Basson CT, Lerman BB, Sasse-Klaassen S, Thierfelder L, MacRae CA, Gerull B (2006) Mutant desmocollin-2 causes arrhythmogenic right ventricular cardiomyopathy. Am J Hum Genet 79:1081-1088

Hwang J, Pallas DC (2013) STRIPAK complexes: structure, biological function, and involvement in human diseases. Int J Biochem Cell Biol 47:118-148

Joshi-Mukherjee R, Coombs W, Musa H, Oxford E, Taffet S, Delmar M (2008) Characterization of the molecular phenotype of two ARVCrelated PKP2 mutations. Heart Rhythm 5:1715-1723

Kachidian P, Vuillet J, Bartoli M, Castets F, Nieoullon A, Kerkerian-Le Goff L (1998) Relationships between striatin-containing neurons and cortical or thalamic afferent fibres in the rat striatum, an ultrastructural study by dual labelling. Neuroscience 85:111-122

Kapprell H-P, Cowin P, Franke WW, Ponstingl H, Opferkuch HJ (1985) Biochemical characterization of desmosomal proteins isolated from 
bovine muzzle epidermis: amino acid and carbohydrate composition. Eur J Cell Biol 36:217-229

Lu Q, Pallas DC, Surks HK, Baur WE, Mendelsohn ME, Karas RH (2004) Striatin assembles a membrane signaling complex necessary for rapid, nongenomic activation of endothelial NO synthase by estrogen receptor $\alpha$. Proc Natl Acad Sci 101:17126-17131

Lyon RC, Mezzano V, Wright AT, Pfeiffer E, Chuang J, Banares K, Castaneda A, Ouyang K, Cui L, Contu R, Gu Y, Evans $\mathrm{SM}$, Omens JH, Peterson KL, McCulloch AD, Sheikh F (2014) Connexin defects underlie arrhythmogenic right ventricular cardiomyopathy in a novel mouse model. Hum Mol Genet 23:1134-1150

Makara MA, Curran J, Little S, Musa H, Polina I, Smith SA, Wright PJ, Unudurthi SD, Snyder JS, Bennett V, Hund TJ, Mohler PJ (2014) Ankyrin-G coordinates intercalated disc signaling platform to regulate cardiac excitability in vivo. Circ Res 115:929-938

Meens MJ, Pfenniger A, Kwak BR, Delmar M (2013) Regulation of cardiovascular connexins by mechanical forces and junctions. Cardiovasc Res 99:304-314

Meurs KM, Spier AW, Miller MW, Lehmkuhl L, Towbin JA (1999) Familial ventricular arrhythmias in boxers. J Vet Intern Med 13: 437-439

Meurs KM, Ederer MM, Stern JA (2007) Desmosomal gene evaluation in boxers with arrhythmogenic right ventricular cardiomyopathy. Am J Vet Res 68:1338-1341

Meurs KM, Mauceli E, Lahmers S, Acland GM, White SN, Lindblad-Toh K (2010) Genome-wide association identifies a deletion in the $3^{\prime}$ untranslated region of striatin in a canine model of arrhythmogenic right ventricular cardiomyopathy. Hum Genet 128:315-324

Meurs KM, Stern JA, Sisson DD, Kittleson MD, Cunningham SM, Ames MK, Atkins CE, DeFrancesco T, Hodge TE, Keene BW, Reine Doreste Y, Leuthy M, Motsinger-Reif AA, Tou SP (2013) Association of dilated cardiomyopathy with the striatin mutation genotype in boxer dogs. J Vet Intern Med 72:1437-1440

Mezzano V, Pellman J, Sheikh (2014) Cell junctions in the specialized conduction system of the heart. Cell Commun Adhes 21:149-159

Mohler PJ, Rivolta I, Napolitano C, LeMaillet G, Lambert S, Priori SG, Bennett V (2004) $\mathrm{Na}_{\mathrm{v}} 1.5$ E1053K mutation causing Brugada syndrome blocks binding to ankyrin- $\mathrm{G}$ and expression of $\mathrm{Na}_{\mathrm{v}} 1.5$ on the surface of cardiomyocytes. Proc Natl Acad Sci U S A 101:1753317538

Moll R, Sievers E, Hämmerling B, Schmidt A, Barth M, Kuhn C, Grund C, Hofmann I, Franke WW (2009) Endothelial and virgultar cell formations in the mammalian lymph node sinus: endothelial differentiation morphotypes characterized by a special kind of junction (complexus adhaerens). Cell Tissue Res 335:109-141

Moreno CS, Park S, Nelson K, Ashby D, Hubalek F, Lane WS, Pallas DC (2000) WD40 repeat proteins striatin and $\mathrm{S} / \mathrm{G}_{2}$ nuclear autoantigen are members of a novel family of calmodulin-binding proteins that associate with protein phsophatase 2A. J Biol Chem 275:5257-5263

Moreno CS, Lane WS, Pallas DC (2001) A mammalian homolog of yeast MOB1 is both a member and a putative substrate of striatin familyprotein phosphatase 2A complexes. J Biol Chem 276:24253-24260

Mueller H, Franke WW (1983) Biochemical and immunological characterization of desmoplakins I and II, the major polypeptides of the desmosomal plaque. J Mol Biol 163:647-671

Muro Y, Chan EKL, Landberg G, Tan EM (1995) A cell-cycle nuclear autoantigen containing WD-40 motifs epxressed mainly in $\mathrm{S}_{\text {and }} \mathrm{G}_{2}$ phase cells. Biochem Biophys Res Commun 207:1029-1037

Murray B (2012) Arrhythmogenic right ventricular dysplasia/ cardiomyopathy $(\mathrm{ARVD} / \mathrm{C})$ : a review of molecular and clinical literature. J Genet Couns 21:494-504

Noorman M, Hakim S, Kessler E, Groeneweg J, Cox MGPJ, Asimaki A, Rijen HVM van, Stuijvenberg L van, Chkourko H, Heyden MAG van der, Vos MA, Jonge N de, Smagt JJ van der, Dooijes D, Vink A,
Weger RA de, Varro A, Bakker JMT de, Saffitz JE, Hund TJ, Mohler PJ, Delmar M, Hauer RNW, Veen TAB van (2013) Remodeling of the cardiac sodium channel, Connexin43 and Plakoglobin at the intercalated disk in patients with arrhythmogenic cardiomyopathy. Heart Rhythm 10:412-419

Oxford EM, Everitt M, Coombs W, Fox PR, Kraus M, Gelzer AR, Saffitz J, Taffet SM, Moise NS, Delmar M (2007a) Molecular composition of the intercalated disc in a spontaneous canine animal model of arrhythmogenic right ventricular dysplasia/cardiomyopathy. Heart Rhythm 4:1196-1205

Oxford EM, Musa H, Maass K, Coombs W, Taffet SM, Delmar M (2007b) Connexin43 remodeling causes by inhibition of plakophilin-2 expression in cardiac cells. Circ Res 101:703-711

Oxford EM, Danko CG, Kornreich BG, Maass K, Hemsley SA, Raskolnikov D, Fox PR, Delmar M, Moïse NS (2011) Ultrastructural changes in cardiac myocytes from boxer dogs with arrhythmogenic right ventricular cardiomyopathy. J Vet Cardiol 13: 101-113

Patel DM, Green KJ (2014) Desmosomes in the heart: a review of clinical and mechanistic analyses. Cell Commun Adhes 21:109-128

Pieperhoff S, Franke WW (2007) The area composita of adhering junctions connecting heart muscle cells of vertebrates. IV. Coalescence and amalgamation of desmosomal and adhaerens junction components-late processes in mammalian heart development. Eur J Cell Biol 86:377-391

Pieperhoff S, Schumacher H, Franke WW (2008) The area composita of adhering junctions connecting heart muscle cells of vertebrates. V. The importance of plakophilin-2 demonstrated by small interference RNA-mediated knockdown in cultured rat cardiomyocytes. Eur J Cell Biol 87:399-411

Pieperhoff S, Borrmann C, Grund C, Barth M, Rizzo S, Franke WW (2010) The area composita of adhering junctions connecting heart muscle cells of vertebrates. VII. The different types of lateral junctions between the special cardiomyocytes of the conduction system of ovine and bovine hearts. Eur J Cell Biol 89:365-378

Pieperhoff S, Rickelt S, Heid H, Claycomb WC, Zimbelmann R, Kuhn C, Winter-Simanowski S, Kuhn S, Frey N, Franke WW (2012) The plaque protein myozap identified as a novel major component of adhering junctions in endothelia of the blood and lymph vascular systems. J Cell Mol Med 16:1709-1719

Posch MG, Posch MJ, Geier C, Erdmann B, Mueller W, Richter A, Ruppert V, Pankuweit S, Maisch B, Perrot A, Buttgereit J, Dietz R, Haverkamp W, Özcelik C (2008) A missense variant in desmoglein-2 predisposes to dilated cardiomyopathy. Mol Genet Metab 95:74-80

Rickelt S (2012) Plakophilin-2: a cell-cell adhesion plaque molecule of selective and fundamental importance in cardiac functions and tumor cell growth. Cell Tissue Res 348:281-294

Rickelt S, Pieperhoff S (2012) Mutations with pathogenic potential in proteins located in or at the composite junctions of the intercalated disk connecting mammalian cardiomyocytes: a reference thesaurus for arrhythmogenic cardiomyopathies as well as Naxos and Carvajal diseases. Cell Tissue Res 348:325-333

Rickelt S, Kuhn C, Winter-Simanowski S, Zimbelmann R, Frey N, Franke WW (2011) Protein myozap - a late addition to the molecular ensembles of various kinds of adherens junctions. Cell Tissue Res 346:347-359

Rizzo S, Lodder EM, Verkerk AO, Wolswinkel R, Beekman L, Pilichou K, Basso C, Remme CA, Thiene G, Bezzina CR (2012a) Intercalated disc abnormalities, reduced $\mathrm{Na}^{+}$current density, and conduction slowing in desmoglein-2 mutant mice prior to cardiomyopathic changes. Cardiovasc Res 95:409418

Rizzo S, Pilichou K, Thiene G, Basso C (2012b) The changing spectrum of arrhythmogenic (right ventricular) cardiomyopathy. Cell Tissue Res 348:319-323 
Ruiz P, Brinkmann V, Ledermann B, Behrend M, Grund C, Thalhammer C, Vogel F, Birchmeier C, Günthert U, Franke WW, Birchmeier W (1996) Targeted mutation of plakoglobin in mice reveals essential functions of desmosomes in the embryonic heart. J Cell Biol 135: $215-225$

Saffitz JE (2007) Cell adhesion pathology. In: Marcus FI, Nava A, Thiene G (eds) Arrhythmogenic RV cardiomyopathy/dysplasia. Recent advances. Springer, Milan, pp 45-51

Saffitz JE (2011) The pathobiology of arrhythmogenic cardiomyopathy. Annu Rev Pathol Mech Dis 6:299-321

Salin P, Kachidian P, Bartoli M, Castets F (1998) Distribution of striatin, a newly identified calmodulin-binding protein in the rat brain: an in situ hybridization and immunocytochemical study. J Comp Neurol 397:41-59

Sato PY, Musa H, Coombs W, Guerrero-Serna G, Patiño GA, Taffet SM, Isom LL, Delmar M (2009) Loss of plakophilin-2 expression leads to decreased sodium current and slower conduction velocity in cultured cardiac myocytes. Circ Res 205:523-526

Sato PY, Coombs W, Lin X, Nekrasova O, Green KJ, Isom LL, Taffet SM, Delmar M (2011) Interactions between ankyrin-G, Plakophilin2, and Connexin43 at the cardiac intercalated disc. Circ Res 109: 193-201

Schmelz M, Franke WW (1990) A new type of intercellular junction: desmosomal proteins in the extended junctions of certain endothelial cells of the lymphatic system. Cell Biol Int Rep 14:54

Schmelz M, Franke WW (1993) Complexus adhaerentes, a new group of desmoplakin-containing junctions in endothelial cells: the syndesmos connecting retothelial cells of lymph nodes. Eur J Cell Biol 61:274-289

Schmelz M, Moll R, Kuhn C, Franke WW (1994) Complexus adhaerentes, a new group of desmoplakin-containing junctions in endothelial cells. II. Different types of lymphatic vessels. Differentiation 57:97-117

Straub BK, Boda J, Kuhn C, Schnoelzer M, Korf U, Kempf T, Spring H, Hatzfeld M, Franke WW (2003) A novel cell-cell junction system: the cortex adhaerens mosaic of lens fiber cells. J Cell Sci 116:4985-4995

Straub BK, Rickelt S, Zimbelmann R, Grund C, Kuhn C, Iken M, Ott M, Schirmacher P, Franke WW (2011) E-N-cadherin heterodimers define novel adherens junctions connecting endoderm-derived cells. J Cell Biol 195:873-887
Tanti GK, Singarapu N, Muthuswami R, Goswami S (2014) Among the striatin family members, SG2NA was first to arise during evolution. Front Biosci (Schol Ed) 6:1-15

van Tintelen JP, Entius MM, Bhuiyan ZA, Jongbloed R, Wiesfeld AC, Wilde AA, Smagt J van der, Boven LG, Mannens MM, Langen IM van, Hofstra RM, Otterspoor LC, Doevendans PA, Rodriguez LM, Gelder IC van, Hauer RN (2006) Plakophilin-2 mutations are the major determinant of familial arrhythmogenic right ventricular dysplasia/cardiomyopathy. Circulation 113:1650-1658

van Tintelen JP, Hofstra RM, Wiesfeld AC, Berg MP van den, Hauer RN, Jongbloed JD (2007) Molecular genetics of arrhythmogenic right ventricular cardiomyopathy: emerging horizon? Curr Opin Cardiol 22:185-192

Vatta M, Yang Z, Towbin JA (2007) Transgenic animal models. In: Marcus FI, Nava A, Thiene G (eds) Arrhythmogenic RV cardiomyopathy/dysplasia. Recent advances. Springer, Milan, pp 61-68

Vreeker A, Stuijvenberg L van, Hund TJ, Mohler PJ, Nikkels PGJ, Veen TAB van (2014) Assembly of the cardiac intercalated disk during preand postnatal development of the human heart. PLoS One 9:e94722

Wiche G (1989) Plectin: general overview and appraisal of its potential role as a subunit protein of the cytomatrix. Crit Rev Biochem Mol Biol 24:41-67

Wiche G, Herrmann H, Leichtfried F, Pytela R (1982) Plectin: a highmolecular-weight cytoskeletal polypeptide component that copurified with intermediate filaments of the vimentin type. Cold Spring Harb Symp Quant Biol 46:475-482

Wiche G, Krepler R, Artlieb U, Pytela R, Denk H (1983) Occurrence and immunolocalization of plectin in tissues. J Cell Biol 97:887-901

Wuchter P, Boda-Heggemann J, Straub BK, Grund C, Kuhn C, Krause U, Seckinger A, Peitsch WK, Spring H, Ho AD, Franke WW (2007) Processus and recessus adhaerentes: giant adherens cell junction systems connect and attract human mesenchymal stem cells. Cell Tissue Res 328:499-514

Yu XX, Du X, Moreno CS, Green RE, Ogris E, Feng Q, Chou L, McQuoid MJ, Pallas DC (2001) Methylation of the protein phosphatase aA catalytic subunit is essential for association of $\mathrm{B} \alpha$ regulatory subunit but not SG2NA, striatin, or polyomavirus middle tumor antigen. Mol Biol Cell 12:185-199 